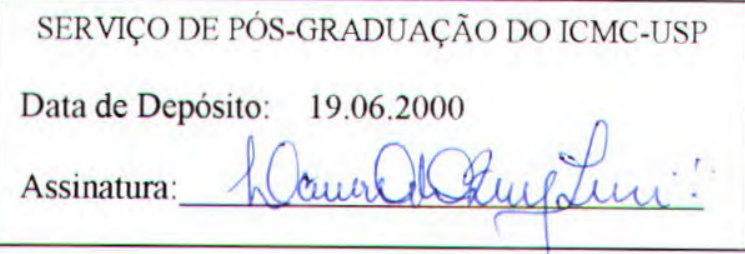

\title{
Uma Ferramenta para Auxiliar na Avaliação Estrutural de Hipermídia Educacional na Web
}

\section{Daniela Marques}

Orientadora: Profa. Dra. Renata Pontin de Mattos Fortes

Dissertação apresentada ao Instituto de Ciências Matemáticas e de Computação - ICMC-USP, como parte dos requisitos para obtenção do título de Mestre em Ciências - Área: Ciências de Computação e Matemática Computacional.

USP - São Carlos

Junho de 2000 
Dedico este trabalho aos meus pais: Álvaro e Anna, por tudo que fizeram e fazem por mim. 


\section{Agradecimentos}

A Deus pela oportunidade de poder estar realizando este trabalho e estar aqui neste mundo hoje.

À minha família, meus pais Álvaro e Anna, minhas irmãs Dá, Ivânia, Dina e Ni, meus sobrinhos Luis e Lia pelo carinho, amor, incentivo e paciência durante toda essa etapa, que compreendem a minha ausência e me apoiam em cada decisão que tomo.

À Renata pela oportunidade, confiança, carinho e por me orientar nos momentos em que tudo parecia muito difícil.

À Rosely que me adotou nesses últimos meses, obrigada pelo carinho, compreensão e apoio.

As minhas companheiras de rep, Maris e Renata, pelos bons momentos de descontração. $\grave{A}$ Paula, que se tornou uma grande amiga, obrigada pela amizade, companheirismo e paciência.

Ao Enzo que foi um grande companheiro e que me ajudou imensamente na realização deste trabalho.

Agradeço também a todos os amigos que diretamente ou indiretamente, com uma simples palavra ou com sua simples presença, ajudaram-me de alguma forma nesta etapa da minha vida. Em especial aos freqüentadores da "Casa do Walter" (Claudia, Cláudio, Dino, Eglen, Gedson, Renato, Waine, Walter e Will), ao pessoal do DC da Fed (André, Bianchi, Ex-Sanague, Marcelo, Renato, Sandro, e principalmente ao Mário, Eli e Val), ao pessoal de every-day do Labes (Jana, Aline, Elisandra, Tati, Adenilso, Willie, Rejane e Andrea) e ao meu amigo Marquinhos, que apesar da distância esteve sempre presente. (:)

A CAPES pelo apoio financeiro.

A todos do ICMC que me ajudaram de uma forma ou outra para a realização deste trabalho.

A todos, muitíssimo obrigada. 


\section{Sumário}

LISTA DE FIGURAS ………………………............................................................

LISTA DE TABELAS ........................................................................................ IV

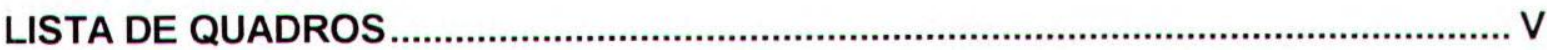

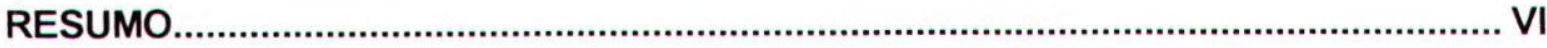

ABSTRACT

1. INTRODUÇÃO

1.1 OBJETIVOS DA DISSERTAÇÃO ............................................................................................................. 2

1.2 ORGANIZAÇÃO DO TRABALHO ............................................................................................................ 3

2. HIPERMIIDIA NA EDUCAÇĀO ..................................................................................

2.1 CONSIDERAÇÕES INICIAIS .............................................................................................................. 4

2.2 PARADIGMAS DA INFORMÁTICA NA EDUCAÇĀO................................................................................5

2.3 CARACTERISTICAS DAS APLICAÇōES HIPERMIIDIA EDUCACIONAIS .................................................. 7

2.4 CONSIDERAÇŌES FINAIS ..........................................................................................................................10

3. QUALIDADE DE SOFTWARE .......................................................................11

3.1 CONSIDERAÇÕES INICIAIS ....................................................................................................................... 11

3.2 QUALIDADE DE SOFTWARE................................................................................................................... 11

3.3 MÉTRICAS DE SOFTWARE ..................................................................................................................... 14

3.4 QUALIDADE EM HIPERMIDIA ............................................................................................................ 15

3.5 QUALIDADE EM HIPERMIDIA EDUCACIONAL ............................................................................... 24

3.6 CONSIDERAÇÕES FINAIS .................................................................................................................... 27

4. AVALIAÇÃO ESTRUTURAL PARA HIPERMIDIA EDUCACIONAL.........................29

4.1 CONSIDERAÇÕES INICIAIS ..................................................................................................................29

4.2 AVALIAÇÃo ESTRUTURAL EM HIPERMIDIA EDUCACIONAL ............................................................. 29

4.3 CONSIDERAÇÕES FINAIS ...........................................................................................................................37

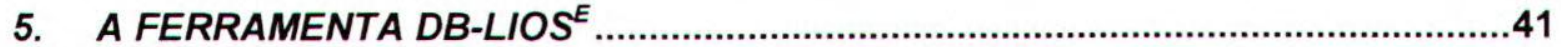

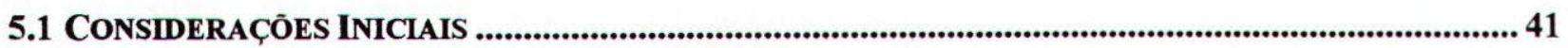

5.2 CARACTERISTICAS DA FERRAMENTA DB-LIOS..............................................................................42

5.3 FERRAMENTA DB-LIOS ${ }^{E}$ E SUAS FUNÇŌES ........................................................................................4 43

5.3.1 Modelagem Dinâmica - Diagrama de Estados ........................................... 45

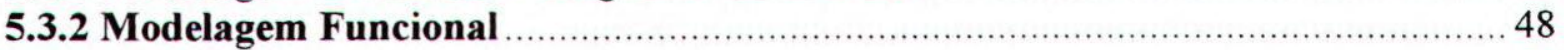

5.4 ESTUDOS DE CASOS............................................................................................................................. 51 
5.4.1 Estudos de Casos no Domínio Educacional

5.4.2 Estudos de Casos Independentes de Domínio 


\section{Lista de Figuras}

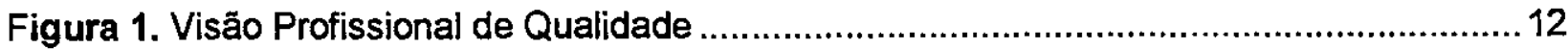

Figura 2. Elementos Chaves do TQM (Kan, 1994) .................................................... 13

Figura 3. Abordagem Bottom-up e Top-down (Nanard \& Nanard, 1995) ............................ 17

Figura 4. Etapas do Ciclo de Vida por Prototipação Evolutiva (Fortes, 1996) ........................20

Figura 5. Representação estrutural do elemento Link de hiperdocumento da WWW.............21

Figura 6. Esquema de Casos de Reuso de componentes de Links (Fortes, 1996) ................22

Figura 7. Base de Dados Relacional da DB-LiOS (Seraphim, 2000)...................................43

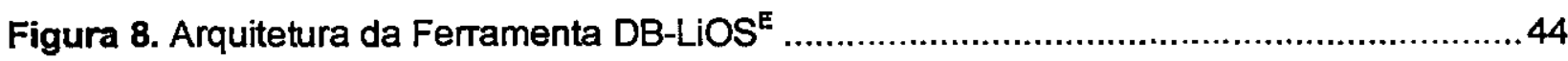

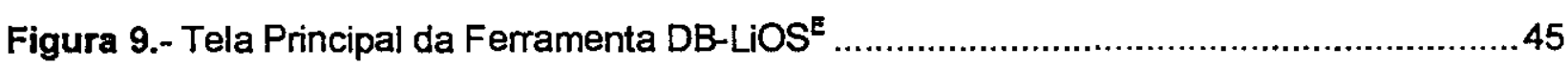

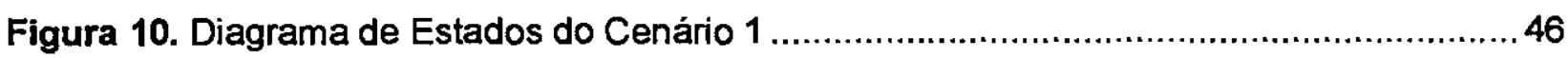

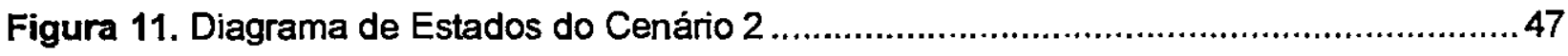

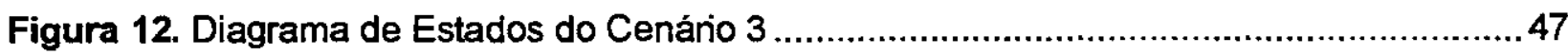

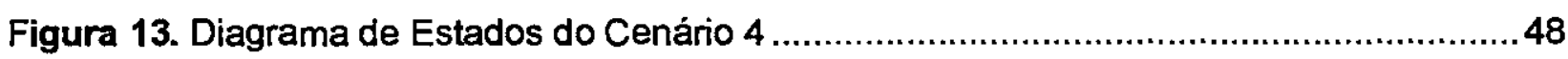

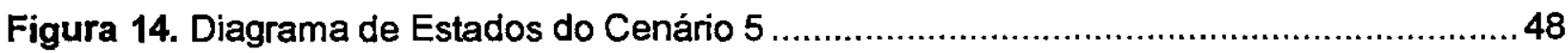

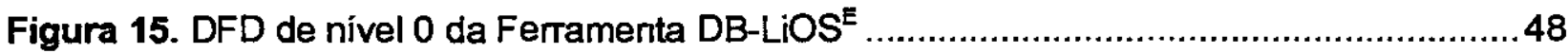

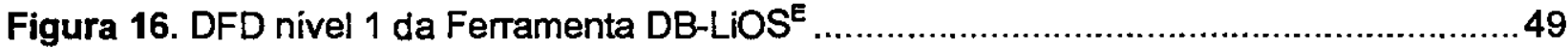

Figura 17. Gráfico dos Percentuais dos Casos Encontrados ..........................................54 


\section{Lista de Tabelas}

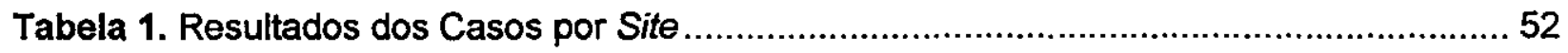


Quadro 1. Decomposição feita para atender o objetivo da Confiabilidade de Representação 25 Quadro 2. Decomposição feita para atender o objetivo da Confiabilidade Conceitual.............26

Quadro 3. Decomposição feita para atender o objetivo da Usabilidade ................................ 26

Quadro 4. Resumo dos critérios de qualidade analisados ................................................39

Quadro 5. Descrições das Funçōes Disponiveis ao Usuário..............................................50 


\section{Resumo}

Atualmente a qualidade deve ser uma caracteristica presente em qualquer produto ou serviço, inclusive em todos os tipos de softwares. As aplicaçōes hipermidia, por sua vez, são compostas por milhares de links e nós de uma forma bastante flexivel, que as tomam facilmente passiveis de erros e merecem atenção para um efetivo controle de qualidade. Além disso, as aplicações hipermídia na Intemet, por meio de páginas da Web, estão aumentando de forma considerável. Uma análise estrutural foi proposta com o objetivo de avaliar a qualidade das ligaçōes de um hiperdocumento Web e uma classificação de casos de reuso de links foi definida. O objetivo deste trabalho é aplicar essa análise estrutural e avaliar os casos de links no domínio educacional, ou seja, identificar o que significa cada caso para esse domínio especifico e fomecer indicativos para que 0 autor possa melhorar sua aplicação hipermidia educacional. 


\begin{abstract}
Currently quality is an essential feature of any product, including all types of software. Hypermedia applications are composed of thousands of links and nodes in such a flexible way that can be easily error-prone and is worth of attention for an effective quality control of software. Moreover, the Intemet hypermedia applications and web pages have been increased considerably. A structural analysis was proposed in order to evaluate the quality of hyperdocument links of Web. The analysis is based on an approach to reuse of link components that was also defined. This work describes how to apply the structural analysis and then evaluate those reuse cases of link components for educational domain. So, this paper presents the meaning of each reuse case of link components according to the educational domain. Also, we discuss how the authors (teachers) can improve the educational hypermedia application by using these meaningful cases of analysis.
\end{abstract}


Atualmente a Internet é vista como uma forma de expressão e um portal de um novo mundo, uma nova forma de relacionamento entre as pessoas e de se fazer negócios (Netz, 1999). Surgiu inicialmente para ser utilizada pelos militares norte-americanos, depois por acadêmicos e usuários privilegiados; atualmente a Internet se tornou acessível no mundo inteiro ao grande público, com um conjunto de recursos e procedimentos tecnológicos que permitem a qualquer pessoa (física ou jurídica) exibir textos e imagens (hiperdocumentos ${ }^{1}$ ) a partir de um equipamento simples $\theta$ através de uma linha telefônica (Blumenschein \& Freitas, 2000).

O uso da Internet se amplia enormemente a cada dia devido principalmente às suas características de fácil utilização, seu baixo custo ao disponibilizar os hiperdocumentos na rede e grande potencial de comunicação oferecido. Mas uma preocupação também crescente diz respeito à qualidade de todos esses hiperdocumentos disponibilizados na rede. Recentemente, a qualidade é exigida em qualquer produto ou serviço e com hiperdocumentos não poderia ser diferente.

Entretanto, como proceder para se avaliar a qualidade de um hiperdocumento é ainda uma questão não totalmente resolvida. Essa questão tem sido bastante discutida, mas concorda-se com Hatzmanikatis et al. (1995), de que uma avaliação da qualidade no hiperdocumento deve surgir a partir de práticas da área de Engenharia de Software e de Métricas de Software.

A Engenharia de Software se preocupa com a qualidade de software durante todo o desenvolvimento do software, assim como do software como produto final. Neste sentido, a Engenharla de Software propõe métricas como forma de medir o indicatlvo da qualidade desejada. Essas métricas não são fáceis de se estabelecer, visto que qualidade é um termo genérico e, dependendo do ponto de vista de cada pessoa, qualidade pode ter um significado diferente. Assim, qualidade de software conta com alguns atributos relevantes que são comuns a qualquer software (por exemplo: a documentação) e outros atributos que dependem do domínio da aplicação, da tecnologia utilizada e das características específicas do projeto e das necessidades da organização (Sommerville, 1989). Por meio da identificação desses atributos

\footnotetext{
' Hiperdocumento é composto por nós, que representam unidades de informações, e links que sāo ligações entre estes nós. Neste trabalho o termo hiperdocumento e hipermídia tendem a ser usados um no lugar do outro, representando aplicações que permitem ao usuário seguir caminhos não lineares através de áudio, vídeo, imagens e textos.
} 
e suas medidas, a qualidade de software pode ser observada. Com as aplicações hipermídia ocorre o mesmo, por exemplo, conforme o domínio da aplicaçāo existem alguns atributos que devem ser considerados para a sua qualificação.

Com a disseminação da Intemet muitas áreas de conhecimento e respectivos domínios de informação têm se beneficiado, e uma delas é a área de hipermídia educacional. A área educacional tem procurado utilizar as novas tecnologias oferecidas no mercado para inovar o aprendizado tradicional. Campos et al. (1999) confirmam essa tendência ao dizerem que o uso do computador pode ser uma ferramenta capaz de propiciar um ensino mais ativo e mudar práticas educacionais ultrapassadas.

Os cursos oferecidos pela televisão já representam a utilização de uma nova tecnologia, mas nesses cursos a interação direta aluno-professor é bastante difícil. As aplicações hipermidia surgem então como uma nova alternativa de forma de aprendizado, onde a interação alunoprofessor é facilitada por meio de e-mail e chats, por exempio, e o material disponibilizado na forma de hiperdocumento possibilita uma exploração flexlvel do seu conteúdo pelo aluno.

\subsection{Objetivos da dissertação}

A realização deste trabaiho foi motivada principaimente pela crescente disseminação da Intemet e de sua utilização como uma altemativa tecnológica para auxiliar ambientes de ensino-aprendizado. Foi considerado também que a construçāo de um hiperdocumento, geralmente, envolve milhares de links e milhares de nós e por este motivo a tarefa para se verificar se a estrutura do hiperdocumento está correta pode se tornar inviável de se fazer manuaimente. Além disso, o desafio de se obter qualidade de software em uma aplicação hipermídia por meio de uma adequação de técnicas da Engenharia de Software.

Este trabaiho investiga as aplicaçōes hipermidia educacionais de forma a definir atributos de qualidade relevantes para este tipo de aplicação e fornecer indicativos de qualidade ao autor da aplicação com base nos atributos considerados. Estes indicativos combinam duas abordagens: a primeira, baseada na análise estrutural do hiperdocumento proposta por Fortes (1996), e a segunda, em alguns atributos propostos para avaliação de hipermidia educacionais de Campos (1994) e Ramos \& Mendonça (1991). A ferramenta DB-LiOS ${ }^{\mathrm{E}}$ (DataBase - Link Oriented System For Education) foi desenvolvida e possibilita que automaticamente se verifique indicativos de qualidade, a proposta não é oferecer um valor de qualidade e sim dar parâmetros ao autor para que ele possa analisar seu site e verificar quais as possibilidades de melhoria. 


\subsection{Organização do trabalho}

Este trabalho está dividido em 6 capítulos. Neste capítulo de Introduçāo foi descrito o trabalho de forma geral, com seus objetivos e motivações.

No Capítulo 2 - Hipermídia Educacional, mostra os paradigmas existentes, como o lado pedagógico é adotado nas aplicaçōes hipermídia e quais as vantagens e desvantagens desse tipo de aplicação.

No Capítulo 3 é discutido sobre Qualidade de Software, qual seu significado, como medir qualidade, o que existe hoje no mercado para melhorar a qualidade em hipermídia $\theta$ especificamente o que existe sobre qualidade em hipermídia educacional.

No Capítulo 4 é descrito o trabalho prático desenvolvido propriamente dito, e mostrado a teoria usada para a definição dos atributos considerados relevantes para hipermídia educacional.

A ferramenta implementada para fornecer automaticamente os indicativos de qualidade considerados relevantes é descrita no Capítulo 5. Finalmente no Capítulo 6 são feitos as conclusões e os trabalhos futuros propostos como continuidade deste trabalho. 


\subsection{Considerações Iniciais}

Buscando descrever informalmente a evolução das abordagens educacionais que têm ocorrido no processo de ensino-aprendizado nos últimos tempos, visualizou-se alguns pontos de destaque. Essa visão não tem o objetivo de apresentar completa e nem detalhadamente os movimentos educacionais dos últimos tempos, somente resume os destaques, sob uma perspectiva bastante simples, de aspectos relacionados com os papéis desempenhados por professores e alunos, bem como da disponibilidade de material didático.

Antigamente, o destaque era de que o professor supostamente sabia "tudo" o que deveria ser transmitido ao aluno, e esse por sua vez tinha que aprender a partir das explicaçöes dadas pelo professor, pois embora existisse acesso a bibliotecas e livros, estes possuiam uma disponibilidade restrita. Nessa época, o professor deveria se julgar com pleno conhecimento da matéria a ser ensinada.

Com o passar dos tempos, e com as informações disponiveis serem de mais fácil acesso, surgiu outro destaque para o processo ensino-aprendizado, de pesquisadores afirmando que todos têm o conhecimento, só é preciso descobri-lo. O professor passava a năo mais precisar explicar "tudo" em sala de aula e os alunos, por sua vez, deveriam pesquisar sozinhos. Porém, essa proposta foi questionada por não ser tão genérica e simples, pois, por exemplo, durante a alfabetização, um professor era imprescindivel para guiar as primeiras descobertas de conhecimento.

Pesquisas recentes revelaram que se um mesmo conhecimento fosse transmitido a duas pessoas distintas, as duas inam aprender de maneiras diferentes. Dessa forma, um novo destaque surgiu, no qual o aluno aprende sozinho, mas é necessária a existência de um professor para guiar o aluno no seu aprendizado.

Mais recentemente, observa-se que a quantidade de informações disponiveis é muito grande e aumenta a cada instante. Novo destaque se apresenta e os papéis do professor e do aluno se transformam. Mas um consenso permanece, de que a relação aluno-professor continua sendo fundamental para o processo ensino-aprendizado. Nessa relação, os professores devem facilitar e estimular a busca de conhecimento por parte dos alunos, e dessa maneira, os 
professores ensinam $\theta$ também aprendem com os alunos e vice-versa (Martins et al., 1999). E se essa relação for boa, as duas partes envolvidas ficam motivadas a fazer um bom trabalho.

Confirmando essa tendência de transformação dos papéis, Masetto e Abreu (1990) dizem que - aluno "aprende" realmente quando este "aprender" significar que o aluno passa a ser o agente principal $\theta$ o responsável pela sua aprendizagem. E que essa aprendizagem está centrada nas capacidades, possibilidades, oportunidades e condições do aluno.

Dentro deste contexto, para que os aiunos possam aprender também com a ajuda de novas tecnologias, atualmente a aplicação hipermídia interativa é uma dąs tecnologias que mais influencia na educação e no treinamento das pessoas (Rada, 1997).

Este capítulo apresenta os estudos realizados sobre a utilização da tecnologia de hipermídia na educação, por ser a linha-mestra de pesquisa neste trabalho de mestrado. Na Seção 2.2 são descritos os paradigmas da informática na educação, ou seja, algumas classificações existentes para os softwares educacionais tendo em vista o lado pedagógico adotado. $\mathrm{Na}$ Seção 2.3 são apresentadas algumas características da aplicação hipermídia na educação, assim como suas vantagens e desvantagens. E finalizando, na Seção 2.4 são feitas as considerações finais sobre o capítulo.

\subsection{Paradigmas da Informática na Educação}

Atualmente, tanto as instituições de ensino, quanto os desenvolvedores de software instrutivo sentem a necessidade de mudanças não só na abordagem educacional, mas também nas formas de se introduzir novas tecnologias (Campos \& Campos, 1997). Aquela abordagem tradicional, na qual vê-se o professor, o quadro-negro e o aluno, está sendo substituída por uma nova abordagem, na quai a interação aluno-professor é muito importante, e os professores devem facilitar e estimular os seus alunos na busca de conhecimento (Martins et al., 1999).

$\mathrm{Na}$ literatura é possível encontrar diversas classificações feitas para o software educacional, que foram definidas conforme a filosofia educacional enfocada. A seguir são resumidas aigumas dessas classificações.

Stahl (1990) e Galvis (1988) citam a classificação proposta por Thomas Dwyer que, considerando a atividade do aprendiz, propõe uma divisão em dois grupos: 
- Software com enfoque do tipo algoritmo: dá ênfase na transmissão de conhecimento do sujeito que sabe para o sujeito que deseja aprender. Neste caso, a função do criador de software é projetar uma seqüência bem planejada para a apresentação do conteúdo.

- Software com enfoque heurístico: o aspécto predominante é a aprendizagem experimental ou por descoberta, devendo o software criar um ambiente rico em situações que 0 aluno deve explorar conjecturalmente.

Seguindo Reggini (1990), as modalidades para o uso do computador na educação são:

- Modalidade dura: a atividade dos alunos resume-se a responder perguntas que aparecem na tela, $\theta$ os erros e acertos são computados. Nesta modalidade não existe nenhuma alegria ou motivação para o uso do software.

- Modalidade branda: as atividades dos alunos não parecem ter um objetivo definido, seus erros são motivos para reflexões e projetos. E quem está no comando dessas atividades é o próprio aluno.

No caso específico de hipermídia educacional, o próprio conceito de hipermídia já conta com a possibilidade de múltiplas representações (por exemplo: áudio, vídeo, imagens e textos) e uma estrutura não linear em que as mídias são conectadas. Dessa maneira, a aplicação hipermídia educacional pode ser classificada como um software com enfoque algoritmo quanto heurístico, pois da mesma maneira em que o autor (professor) pode conduzir através dos links uma sequência de aprendizado, é permitido ao usuário (aluno) navegar livremente pelo hiperdocumento (Campos, 1994). Ramos \& Mendonça (1991) só consideram a visão por parte dos autores $\theta$, portanto, consideram uma aplicação hipermídia somente com enfoque algoritmo.

Seguindo a classificação feita por Reggini (1990), as aplicações hipermídia se enquadram melhor na modalidade branda, pois nesté tipo de aplicação os usuários que estão no comando $\theta$ essas aplicaçōes não se resumem simpiesmente em responder perguntas $\theta$ computar erros. Apesar do aluno não possuir comando total sobre as interações, que a princípio devem ter sido definidas pelos professores, as aplicações hipermídia não seriam exclusivamente de modalidade dura uma vez que geralmente compete ao aluno a interação e em geral, diversas possibilidades de trajeto estão disponiveis.

Segundo Lévy (1995), a memória humana é limitada e extremamente sensivel aos seus processos construtivos (com forte dependência de fatores emocionais e existenciais), além de que existe grande dificuldade em diferenciar as mensagens originais e as elaboraçōes a elas 
associadas. Lévy destaca ainda que o que é mais facilmente acessível na memória è aquilo que possui um maior número de conexões, por exemplo: os mitos, as narrações, as danças, as rimas e os cantos são mesmo as formas de representação que têm mais chance de sobreviver à memória humana.

Dessa forma, se a tecnologia for bem empregada, a chance do usuário aprender é altissima. As técnicas hipermídia, por exemplo, poderão desenvolver novos paradigmas de pensamento (Lévy, 1995) (Machado, 1993). O recurso de manipulação de várias midias pode se transformar em uma nova forma de expressão e comunicação, e será um novo impulso para os usuários e seus aprendizados. Isso significa que o bom uso da informática na educação propiciará experiências educacionais novas e ricas, ou pelo menos tomará muito mais motivadora o ensino efetivado nos moldes tradicionais (Moreira, 1987).

\subsection{Características das Aplicações Hipermidia Educacionais}

Como visto na Seção 2.2 a aplicação hipermidia é uma tecnologia que pode e deve ser usada dentro do ambiente educacional. Nesta Seção são descritas suas características, bem como as vantagens e desvantagens da utilização desta tecnologia.

$\mathrm{Na}$ literatura é possível encontrar diversos trabalhos que citam as características de utilização da aplicação hipermidia educacional. Entre eles, a proposta feita por Campos (1994) foi escolhida como base para este trabalho por trazer uma definição mais completa dentro da literatura sobre hipermídia na educação. Campos (1994) define as características de um hipermídia educacional como:

- Uso de recursos sonoros e visuais,

- Representação de figuras, diagramas ou icones das estruturas de informação e dos comandos,

- Uso de dispositivo para interação como mouse, tela sensivel ao toque,

- Uso de menus (índices),

- Rapidez e facilidade de acesso à informaçăo,

- Interface agradável,

- Conectividade do texto,

- Facilidade de navegação,

- Facilidade em seguir referências,

- Estruturação da informação em hierarquias simples, múltiplas ou em redes,

- Possibilidade de documentos personalizados, 
- Modularidade da informação,

- Possibilidade de trabalho cooperativo,

- Possibilidade de estruturação de documentos multidimensionais,

- Facilidade de apresentação devido às informações serem desdobradas em pequenas janelas,

- Facilidade na apresentação das informaçōes (as janelas onde as informações são apresentadas podem variar em número, tamanho e distribuiçăo),

- As unidades de informaçāo são ligadas por links onde os usuários tem liberdade de navegação,

- Possibilidade de se construir estruturas com diversos propósitos devido às características da aplicaçăo hipermídia, que é composta por páginas e ligaçōes,

- Possibilidade do desenvolvimento do nível da aprendizagem que está sendo realizada,

- Possibilidade de diferentes estilos de aprendizagem,

- Fácil utilização.

Santibañez \& Fernandes (1998) confirmam algumas características quando afimam: "As aplicaçōes hipermídia possuem aspectos relevantes que podem significar um salto qualitativo na educação: capacidade de individualizar a aprendizagem, trabalho cooperativo, facilidade de manipular as informaçōes armazenadas em diferentes midias propiciando uma aprendizagem multisensorial, desenvolvimento de espirito crítico e novas perspectivas para o trabalho do professor".

Segundo Neto et al. (1995), uma vantagem para o uso das aplicaçōes hipermídia no ensinoaprendizado é que estas permitem aos usuários (estudantes) terem acesso a uma grande variedade de informaçōes de uma forma fácil e rápida. Os autores do hipermídia podem sugerir caminhos a serem navegados (através dos nós), e os alunos podem escolher segui-los ou nāo de acordo com seus objetivos. Se os alunos optarem por seus próprios caminhos, eles seguem a sequêencia e organização indicada pela sua mente, construindo seu próprio conhecimento no ritmo e estilo determinados por suas estruturas mentais.

Outra vantagem citada é de que as apiicaçōes hipermídia oferecem potencial para alterar as funçōes de professores e alunos, aumentando assim a interação entre eles. Devido à flexibilidade, o estudante pode traçar suas próprias rotas $\theta 0$ intercâmbio com os demais estudantes e professores pode ser uma fonte riquíssima para o seu desenvolvimento (Amante, 1994). 
Tanto Neto et al. (1995) como Amante (1994), ao fazerem essas afirmaçōes confirmam uma tendência construtivista, ou seja, a ênfase está na autonomia do aluno que interage com o ambiente, que por sua vez tem o foco no processo de construção do conhecimento e não num domínio pré-definido do conhecimento a ser adquirido pelo aprendiz (abordagem tradicional) (Akhras \& Self, 1995). A colocação feita por Campos (1994) de que existe um ambiente heuristico nas aplicaçōes hipermídia é confirmada.

Neste contexto, o controle que o aluno é capaz de ter sobre o material didático em aplicações hipermídia é uma questão importante devido à responsabilidade que ele passa a ter no processo de aprendizagem (Large, 1996).

Apesar das diversas vantagens das aplicaçōes hipermídia educacionais, existem algumas desvantagens que devem ser consideradas. Algumas desvantagens inerentes à tecnologia de hipermídia são:

- sobrecarga cognitiva: sobrecarga no esforço e concentraçāo exigidos do usuário devido à necessidade de se manter várias tarefas ou caminhos ao mesmo tempo (Conklin, 1987);

- desorientação do usuário: tendência do usuário se perder na navegação do hiperdocumento (Halasz, 1988);

- falta de coerência: muitas vezes o usuário constrói um modelo mental que não reflete o proposto pelo autor. Para aumentar a coerência entre os nós, os autores devem utilizar recursos para ajudar os usuários a identificarem os principais componentes do hiperdocumento e a maneira na qual eles constituem sua estrutura global (Thüring et al., 1995).

Além das desvantagens citadas, no contexto educacional existe uma outra preocupação: os autores devem deixar disponível um amplo material estruturado aos usuários, não tendo como objetivo simplesmente 0 acesso a essas informações, mas sim a meta de que as informações sejam aprendidas pelos usuários (Silva et al., 1998).

Barker et al. (1993) destacam também que o software educacional só terá sucesso se possuir um projeto e uma estrutura adequados ao ambiente de aprendizagem. E para que seja felto um bom projeto, o mesmo deve contar com a colaboração de alunos, professores, projetistas e programadores. Ou seja, a aplicação hipermídia educacional deve atender a dois aspectos: 0 educacional ou pedagógico, e o técnico computacional [(Carraher, 1990) apud (Ramos \& Mendonça, 1991)]. 


\subsection{Considerações Finais}

Neste capltulo foram apresentados alguns paradigmas da informática na educação, caracteristicas que devem constar nas aplicações hipermídia educacionais e suas vantagens e desvantagens. A partir desse estudo, observou-se que apesar da aplicação hipermídia educacional apresentar problemas, estes devem ser atacados, uma vez que a hipermidia educacional tem muito a oferecer como motivação para inovar o ambiente pedagógico.

Mas a utilização das novas tecnologias em ambiente de ensino-aprendizado deve ser feita de forma criteriosa, para que os alunos realmente possam aprender. Portanto, na criação de uma aplicação hipermídia educacional devem ser sempre considerados os professores, os programadores, e os alunos, para que todos apresentem seus pontos de vista. Além das opiniōes dadas pelos colaboradores, a aplicação hipermídia educacional deve ser desenvolvida de forma a atender da melhor maneira possível tudo o que foi sugerido e, dessa forma, ao final apresentar uma aplicação hipermídia com qualidade.

Para que efetivamente haja o desenvolvimento de uma aplicação hipermídia com qualidade, bem como se saiba o grau de qualidade da aplicação hipermídia criada, existe a necessidade de uma contínua avaliaçăo tanto por parte dos técnicos da área computacional quanto da área pedagógica.

Para discutir os principais aspectos desta avaliação necessária, o próximo capítulo apresenta conceitos de qualidade de software em geral. O que é qualidade? Como obtê-la? Em particular, foi estudado o que é qualidade em hipermídia (para todos os domínios e especificamente para o domínio educacional) e algumas propostas existentes na literatura para conseguir qualidade em hipermídia. 


\section{Qualidade de Software}

\subsection{Considerações Iniciais}

Atualmente há uma tendência mundial em se obter qualidade e aumentar a produtividade, observando que essa produtividade deve vir sempre acompanhada de qualidade. A qualidade deixou de ser um atributo de luxo, hoje é considerada necessidade básica para luta no mercado. Assim sendo, os desenvolvedores de software (produto) também sentem a necessidade de qualidade no software, pois isto é exigido pelos usuários finais. Ao se adquirir um software, é exigido que o mesmo tenha qualidade e que não seja a um custo exorbitante.

Neste capítulo são abordados conceitos relativos à qualidade na Seção 3.2. Na Seção 3.3 é apresentado como a Engenharia de Software pode contribuir para responder a pergunta: "Como se obter qualidade em um produto de software?", ou seja, são descritas métricas de software. Na seqüência, a Seção 3.4 apresenta as considerações de qualidade de software em aplicaçōes hipermídia, são apresentados também alguns métodos, abordagens $\theta$ métricas revisadas da literatura. Na Seção 3.5 é discutido o conceito de qualidade em hipermídia educacional e são descritos alguns critérios de qualidade que devem ser considerados em hipermídia educacional. E finalmente, na Sessão 3.6 são apresentadas às considerações finais sobre este capítulo.

\subsection{Qualidade de Software}

Atualmente, qualidade de software é um termo bastante difundido. $O$ termo vem sendo muito utilizado, pois seguindo histórico da Engenharia de Software, os anos 90 são a era da qualidade (Pressman, 1995).

De fato, qualidade é uma meta a ser perseguida, uma palavra de uso genérico e não de uso exclusivo do software, portanto não é simples sua definição (Manns \& Coleman, 1988).

De acordo com a norma ISO (ISO/CD8402, 1990), "qualidade é a totalidade das características de um produto ou serviço que the confere a capacidade de satisfazer as necessidades implícitas de seus usuários". Pressman (1997), no contexto de Engenharia de Software, define qualidade de software como: "conformidade a: a) os requisitos de desempenho e de funcionalidade definidos, que foram atendidos explicitamente, b) os padrōes de 
desenvolvimento explicitamente documentados e c) as características que são esperadas por todo software desenvolvido por profissionais".

De modo geral, qualidade de software pode ser definida como um conjunto de atributos de software que devem ser satisfeitos de modo que o software atenda às necessidades dos usuários (qualidade externa) e dos desenvolvedores (qualidade interna) (vide Figura 1). Ghezzi et al. (1991) citam ainda que os usuários estão geralmente preocupados somente com a qualidade externa, pois se esquecem de que é através da qualidade interna que se obtém uma qualidade externa.

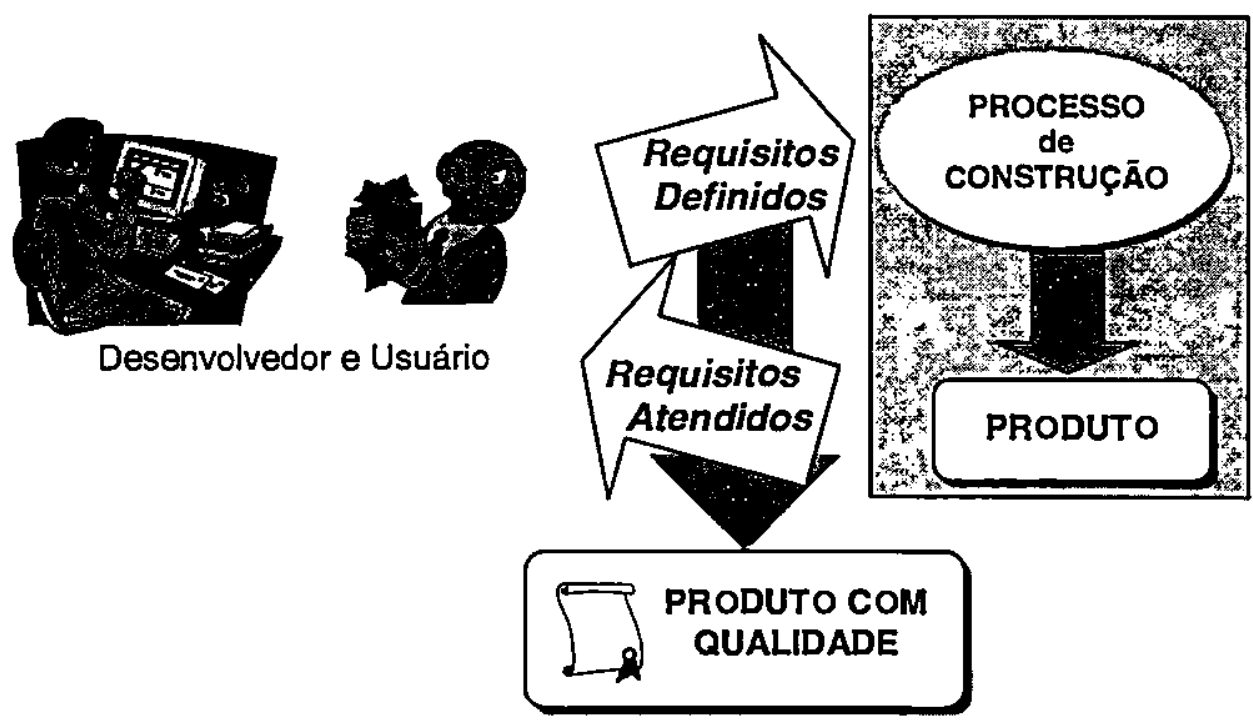

Figura 1. Visão Profissional de Qualidade

Mas como definir essas necessidades dos usuários e dos desenvolvedores para que o software tenha qualidade? A determinação dos atributos relevantes para cada software varia em função do domínio da aplicação, das tecnologias utilizadas, das características específicas do projeto e das necessidades do usuário e da organização (Sommerville, 1989).

Segundo Kan (1994), qualquer área que deseja obter qualidade em seus produtos ou serviços pode utilizar o método de "Gerenciamento da Qualidade Total", o TQM (Total Quality Management). Este método é utilizado para criação de uma cultura na qual todos os membros da organização participem nos processos de melhoramento de produtos e serviços.

Kan (1994) considera quatro elementos chaves do TQM, são eles:

1) Focos do cliente: obter com êxito a satisfação total do cliente; 
2) Processos de melhoramento: definir processos necessários e atingir o processo de melhoramento contínuo;

3) Lado humano da qualidade: criar uma cultura de qualidade em toda a organização e

4) Métricas, modelos, medidas e análises: conduzir o melhoramento contínuo em todos os parâmetros da qualidade para um sistema orientado a metas.

A Figura 2 mostra esquematicamente a representação do TQM. Analisando essa figura tornase claro que para se obter a qualidade total, todos os elementos de suporte devem ser satisfeitos, e, além disso, as métricas, modelos, medidas e análises compõem a base do modelo de qualidade e são os elementos fundamentais para o melhoramento contínuo da qualidade.

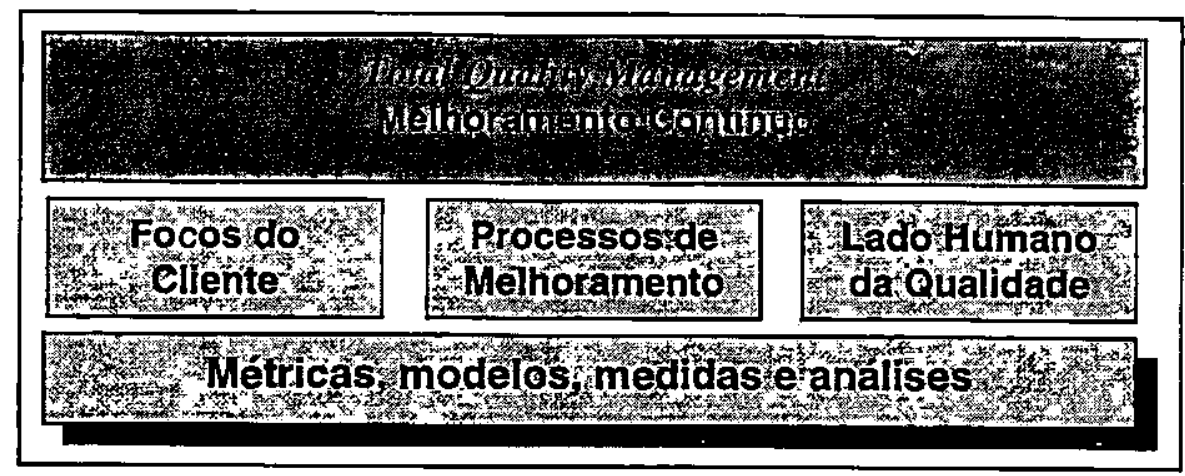

Figura 2. Elementos Chaves do TQM (Kan, 1994)

Assim como no TQM, o software deve ter todos os elementos satisfeitos para que exista a qualidade total. No software a qualidade deve ser medida em todo o seu ciclo de vida e, portanto deve considerar ambos: processo e produto. Pois um software que foi desenvolvido com qualidade (processo), não implica em um produto final com qualidade. E um produto final de software com qualidade, muitas vezes, nāo significa que durante o seu desenvolvimento a qualidade tenha sido alcançada.

Um ponto diferencial de software é que uma vez que seus requisitos não estejam bem especificados, o produto de software pode ser considerado com defeito ou sem qualidade. A qualidade de software deve ser medida, definida, monitorada, gerenciada e melhorada (Pressman, 1997), ou seja, uma visāo profissional de qualidade, adotada para que a melhoria continua seja alcançada à medida que as tecnologias sejam inovadas (Figura 1).

\footnotetext{
${ }^{2}$ O termo "melhoramento contínuo" ou "melhoria continua" será utilizado ao longo do texto por ser de fácil entendimento e esses termos se referem a melhoria continua de qualidade de software.
} 
Especificamente para softwares (produtos e processos), a área de Engenharia de Software fomece métricas para identificar melhor os atributos dos modelos criados e dessa maneira, garantir qualidade nos produtos da engenharia ou nos sistemas que são construídos.

\subsection{Métricas de Software}

Conforme visto, as métricas são uma das bases para o modelo de qualidade e os elementos fundamentais para o melhoramento contínuo. As métricas de software podem ser usadas para (Fenton \& Pfleeger, 1997) (Pressman, 1997):

- indicar a qualidade do produto e do processo e, melhorá-los;

- auxiliar a avaliaçăo da produtividade dos que desenvolvem o produto;

- mostrar benefícios derivados de novos métodos e ferramentas de engenharia de software;

- formar uma base para as estimativas;

- ajudar na justificativa de aquisição de novas ferramentas ou de treinamentos adicionais;

- auxiliar na avaliação do progresso do projeto durante o desenvoivimento.

As medidas de software são classificadas em: medidas diretas e medidas indiretas (Fenton, 1991) (Pressman, 1995). As medidas diretas são aqueias obtidas diretamente de quantidades observáveis, tais como: custo, esforço, linhas de código, velocidade de execuçăo, memória e número de erros. As medidas indiretas sāo aquelas que năo podem ser obtidas diretamente dos itens relacionados ao software, por exemplo: funcionalidade, qualidade, complexidade, eficiência, confiabilidade e manutenibilidade.

Apesar de existirem medidas indiretas, existem muitos trabalhos que propõem se transformar medidas indiretas em medidas diretas, ou seja, derivar a partir de medidas quantitativas, medidas qualitativas de modo a estimar o atributo especificado. $\mathrm{Na}$ próxima seção uma abordagem que auxilia na transformação de medidas indiretas em medidas diretas é apresentada. Mesmo assim, esta não é uma tarefa trivial, as métricas de software não são simples de se obter, pois existem diferentes pontos de vista de qualidade para um mesmo produto e muitas vezes essa decomposição se toma subjetiva.

Por exemplo, quais seriam os atributos de qualidade quando se deseja comprar um software? Neste simpies exempio pode-se ter 3 visões diferentes: a dos usuários, dos desenvolvedores $e$ da organizaçăo. Os usuários têm como atributos de qualidade a facilidade de uso, o desempenho e a confiabilidade dos resuitados. Os desenvolvedores já verificam aiém dos requisitos que o usuário espera, os requisitos internos de um software (taxa de defeito e faciilidade de manutenção, por exemplo). E a organização, por sua vez, avaiia a qualidade 
através dos aspectos de desempenho dos desenvolvedores e também dos aspectos de custo e cronograma.

Dessa forma, é difícil considerar uma característica singular para qualidade de software. Mas a determinação de atributos de qualidade exigidos para um determinado produto é o primeiro passo em busca da qualidade. Além de se determinar atributos, é necessário que exista um procedimento que possa acompanhar passo a passo à evolução de qualidade (Rocha, 1998).

Na próxima seção, são apresentadas as particularidades dos conceitos de qualidade no âmbito das aplicações hipermídia.

\subsection{Qualidade em Hipermídia}

A partir da última década, tem havido um interesse crescente no desenvolvimento das aplicações hipermídia como uma nova forma de Tecnologia de Informação. A popularização da hipermídia ocorreu principalmente com a Internet, devido à facilidade de acesso/distribuição de hiperdocumentos a um baixo custo no ambiente WWW (Word Wide Web), e devido ao seu grande potencial de comunicação. $O$ ambiente WWW pode ser considerado um exemplo de sistema hipermídia bem sucedido com a adoção das novas tecnologias (sistemas distribuídos, arquitetura cliente/servidor, por exemplo). A WWW proporciona basicamente a publicação de hiperdocumentos, permitindo ao usuário a navegação livre pelas páginas com informações representadas por diversas mídias e estruturadas através de links.

Mas mesmo com sua freqüente utilização, existem problemas inerentes à utilização de hiperdocumentos que não podem ser desprezados. A construção de um hiperdocumento, geralmente, envolve a montagem de centenas de nós e milhares de links, e isso pode acarretar um grande potencial de erros. Além disso, principalmente quando existe um grande volume de informações, nota-se com mais freqüência os problemas típicos durante a navegação pelo hiperdocumento: sobrecarga cognitiva, desonientação do usuário e falta de coerência. Esses problemas, já citados anteriormente, são comumentes encontrados, independente do domínio de informações ao qual a hipermídia pertence.

Os problemas citados prejudicam a qualidade do hiperdocumento como um todo e, por isso, são motivos de vasta pesquisa. Um dos primeiros trabalhos a se preocupar com qualidade em hipertextos foi o de Brown (1990). Ele conclui que a avaliação deve sempre contar com o bom senso dos desenvolvedores do hiperdocumento, mas que o auxílio de ferramentas automáticas 
para análise das características do hiperdocumento é essencial como suporte a essa atividade humana.

Stotts et al. (1992) propuseram um método para avaliação de hiperdocumentos bàseada somente no comportamento dos links. Os autores enfatizam que a navegação adequada para hiperdocumentos depende das capacidades, características e auxílios de navegação suportada pelo browser ${ }^{3}$, exemplificando: se um leitor navega para um nó que não possui nenhum link de saída, o único recurso disponivel para continuar sua navegação é voltar à página anterior ou inicial através dos recursos do browser. O método proposto reduz essa ênfase no browser e destaca a estrutura do hiperdocumento. Este método analisa as propriedades semânticas de um hiperdocumento verificando somente os links. A verificação das propriedades de navegação é feita com base no traço do autômato de links (links-automaton). Desta forma, o método pode ser aplicado qualquer que seja o browser, bastando a disponibilização da operação: seguir a direção do link.

Já o método de Stotts et al. (1992) requer o esforço do autor para criar um modelo mental abstrato do hiperdocumento. Ao invés de visualizar os links de um hiperdocumento como um grafo direcionado estático, os links são vistos como a definição de um programa abstrato, denominado pelos autores de autômato de links de hiperdocumentos. Portanto, o ponto forte do método está na obtenção das seqüências de links permitidas durante a navegação.

Nanard \& Nanard (1995) propuseram uma abordagem para avaliação de hipermídia na qual a preocupação é com a qualidade do projeto do hiperdocumento. Além disso, consideram que o desenvolvimento real de um hiperdocumento não segue apenas os passos de um método formal, mas também um projeto mental. As etapas de um método formal são: modelagem de domínio, modelagem de navegação, projeto de interface, implementação e realização de testes. As etapas de um projeto mental são: geração de material, organização e estruturação, reorganização e alteração e, avaliação.

Para suportar as etapas citadas, Nanard \& Nanard (1995) recomendam o uso de feedback loops rápidos e de prototipação para facilitar a atividade de avaliação e o processo de recursão; a abordagem bottom-up e top-down para estimular as atividades de estruturação e alteração e de reuso ao nivel de instância para geração de material. A abordagem bottom-up e top-down proposta é ilustrada na Figura 3.

\footnotetext{
${ }^{3} E$ uma ferramenta que permite a navegação pelo ambiente WWW, assim como outros recursos disponíveis na Internet.
} 


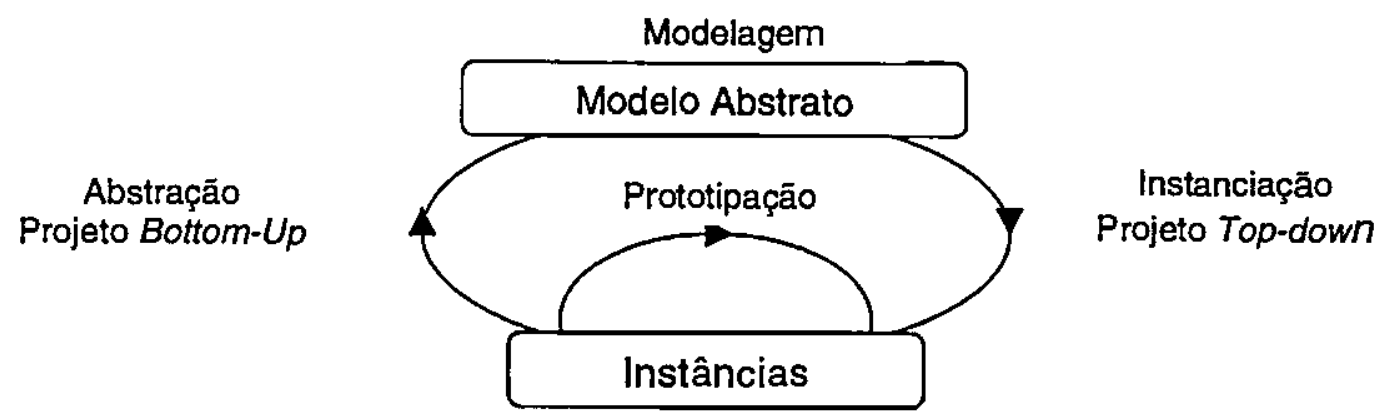

Figura 3. Abordagem Bottom-up e Top-down (Nanard \& Nanard, 1995)

O processo representado na Figura 3 abstrai modelos genéricos a partir de instâncias (exemplos) em um sentido e, no outro, instancia modelos para a implementação e construção de aplicações.

Outro método para avaliação de qualidade foi proposto por Garzotto et al. (1995). Conhecido como método de avaliação "Orientado a Projetos", Garzotto et al. mostraram sua utilização em uma aplicação comercial, ou seja, o método foi aplicado no software "Art Galery" da Microsoft. O método proposto tem como objetivo avaliar o projeto da aplicação hipermídia. As cinco dimensões de estrutura consideradas pelos autores para analisar uma aplicação hipermídia são: conteúdo, estrutura, apresentação, dinâmica e interação, que são explicadas a seguir:

- Conteúdo: refere-se ao tipo de informação que é incluída na aplicação. Esses tipos podem ser: mídia estática (como dados formatados - por exemplo: data, cadeias de caracteres, imagens e gráficos) ou mídia ativa (como vídeos, trihas sonoras e animações). O conteúdo pode ser a dimensão mais importante na avaliação de uma aplicação hipermídia, mas para que seja feita, é necessário um especialista do domínio da aplicação, assim como um conhecimento profundo do perfil dos usuários finais $\theta$ de suas atividades.

- Estrutura: refere-se a organização do conteúdo.

- Apresentação: refere-se a como o conteúdo e as funções da aplicação são mostrados aos usuários. Para apresentação da mídia estática somente uma exibição das informaçōes ("display") é necessária, mas no caso da mídia ativa é exigida uma elaboração melhor para que possa ser exibida ("playing").

- Dinâmica: como os usuários interagem com as informações e interagem através delas (por exemplo, o controle de uma mídia ativa).

- Interação: refere-se a verificação da funcionalidade da dinâmica da aplicação pela operação dos elementos da apresentação. Levando em consideração que a interação 
combina os fatores de dinâmica e apresentação, muitos autores consideram a interação como parte da dinâmica ou apresentação.

O método de avaliação "Orientado a Projeto", proposto por Garzotto et al., considera além das dimensões já descritas, um subconjunto de critérios de avaliação. O subconjunto considerado é composto pelos seguintes atributos:

- Riqueza: expressa a abundância de itens de informação e os caminhos disponíveis para se obtê-los.

- Facilidade: mede o grau de facilidade dos usuários acessarem as informações e o grau de entendimento das operações necessárias para conseguir este acesso.

- Consistência: regularidade da aplicação, em outras palavras significa avaliar a forma de tratamento de elementos com conceitos similares ou distintos.

- Auto-evidência: expressa a facilidade do usuário adivinhar o significado e o propósito das informações que são exibidas. Essas informações podem se referir a conteúdo ou a elementos de navegação.

- Prevlsibilldade: expressa a facilidade do usuário de prever um resultado de uma operação.

- Legibilidade: fator de qualidade considerado por Hatzmanikatis et al. (1995). Por Garzotto et al. (1995) expressa todas as opiniões sobre a validade da aplicação e os autores também consideram que a legibilidade depende de todos os atributos descritos (riqueza, facilidade, consistência, auto-evidência e previsibilidade).

- Reuso: vlsa à reutilização de objetos e operações em diferentes contextos e para diferentes propósitos. Algumas razões pelas quais o reuso deve ser utilizado são: promover consistência e previsibilidade, diminuindo a sobrecarga cognitiva e apresentar o material sob diferentes perspectivas e pontos de vista, enriquecendo a aplicação. Além disso, o reuso possui outras vantagens originadas da Engenharia de Software, por exemplo: reduzir erros, esforços de desenvolvimento e minimizar espaço físico.

Atualmente, Garzotto \& Paolini (1999) discutem sobre os problemas da usabilidade nas aplicações hipermídia, assim como os esforços feitos no projeto da aplicação. Um modelo baseado em uma metodologia de avaliação foi então proposto e conta com duas idéias básicas que são: 1) Inspeção - avaliação da aplicação hipermídia por um expert, sem a interferência de usuários, 2) Executar essa inspeção eficlentemente. Essas inspeçరes são feitas através de patterns de inspeção, que conta com diretrizes que devem ser consideradas pelo inspetor ao encontrar inconsistências e problemas de usabilidade. 
Bernstein (1998) acredita que os problemas das aplicaçōes hipermídia são devido à falta de vocabulário comum para descrever a estrutura de um hipertexto. Dessa forma, ele identifica nove estruturas comuns que podem ser úteis para descrição, análise e talvez para um complexo projeto de hipertexto. As nove estruturas propostas são: cycle, counterpoint, mirronworld, tangle, sieve, montage, splitjoin, missing link e feint.

Após o estudo desses métodos e abordagens que visam qualidade de hipermídia, as métricas propostas, também com esse objetivo, são discutidas a seguir. Pois, os métodos norteiam os indicativos de qualidade de aplicaçōes hipermídia, seja como produto, seja durante o seu desenvolvimento. Mas, para suporte a esses indicativos, é necessária a identificação de dados uniformemente observáveis. A partir da coleta de tais dados é possivel, então, fornecer medidas para os indicativos de qualidade.

As primeiras métricas definidas com a finalidade de avaliar automaticamente um hiperdocumento foram propostas por Botafogo et al. (1992). As métricas sāo baseadas em grafos e foram sugeridas com o intuito de auxiliar o autor; portanto cabe ao autor decidir se os resultados são úteis ou não. As métricas propostas por Botafogo foram: compactação e estratificação.

Hatzmanikatis et al. (1995) utilizam o modelo hierárquico Fator-Critério-Métrica (FCM) - modelo criado por McCall (1977), muito utilizado na área de Qualidade de Software - para definir suas métricas. Os dois importantes fatores de qualidade em hiperdocumento considerados são: Legibilidade e Manutenibilidade. As métricas propostas foram: tamanho, complexidade do caminho, impureza da árvore, modularidade e complexidade individual do nó.

Yamada et al. (1995) propuseram outras métricas de avaliação para aplicações hipermídia. Com base também no trabalho desenvolvido por Botafogo et al. (1992), os autores propuseram três métricas: superficialidade da interface (interface shallowness), compactaçäo incomparável (downward compactness) e navegabilidade incomparável (downward navigability).

O trabalho desenvolvido por Yamada et al. tem como foco principal às métricas para avaliação de museus. Os autores consideram que em aplicaçōes hipermídia para museus existem limitaçōes, tais como: o usuário nāo faz um treinamento para utilização do sistema; o tempo para uso do sistema é limitado e as idades e níveis de conhecimento dos usuários são diversos. Devido a essas limitaçōes, os autores consideram que as aplicações hipermídia para museus devem ser claras e simples. 
Um software possui um cicio de vida para auxiliar seu desenvolvimento $\theta$ as métricas para auxiliar na avaliação de qualidade do software. Nas aplicaçōes hipermídia isso também é necessário. Por esse motivo, é apresentado (Figura 4) um modelo de ciclo de vida de prototipação evolutiva para hiperdocumento proposto por Fortes (1996).

Este ciclo de vida consiste de quatro etapas: Análise de Requisitos, Autoria, Exame para Avaliaçāo e Reorganização. Apesar das etapas serem semelhantes às atividades de um ciçlo de vida por prototipação da área de Engenharia de Software, neste ciclo de vida há uma abordagem evolutiva. Assim sendo, os protótipos não são descartados a cada exame de avaliação, mas sim melhorados cada vez mais para que se alcance uma aplicação hipermídia com qualidade.

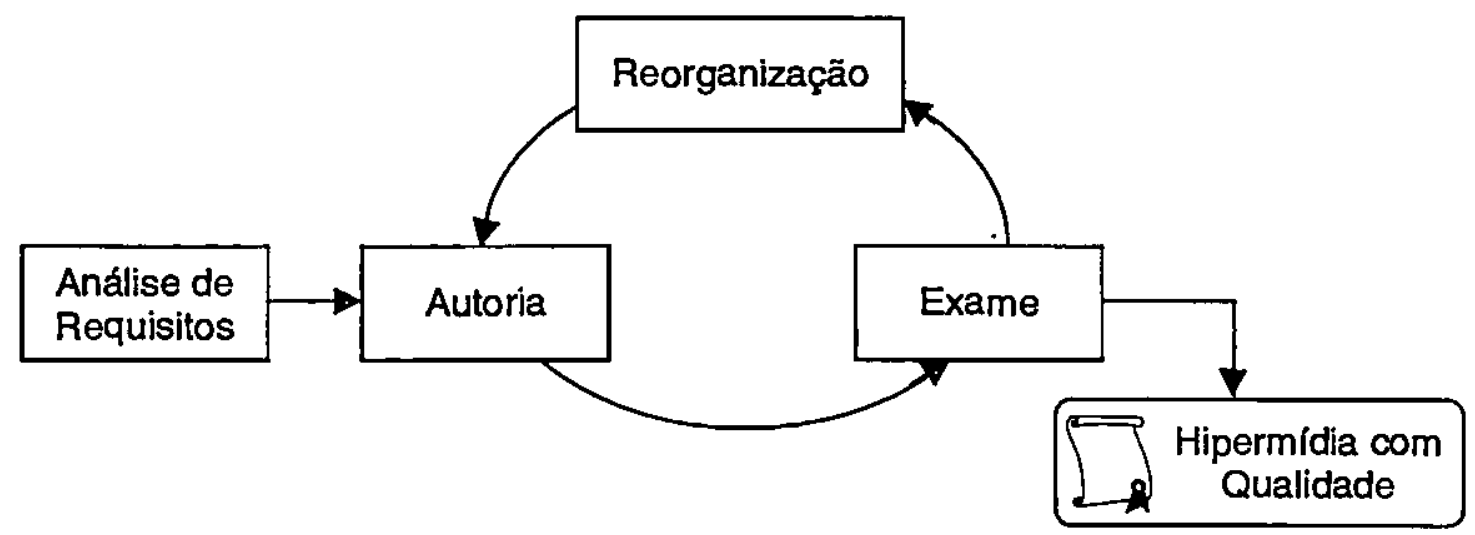

Figura 4. Etapas do Ciclo de Vida por Prototipação Evolutiva (Fortes, 1996)

A etapa de Análise de requisitos engloba aţividades como: identificação das necessidades de desenvolvimento da aplicação; identificação dos objetivos do hiperdocumento; análise de mercado e do usuário; levantamento das restrições gerais de software e de hardware; identificação do domínio de informaçōes e de suas fontes; obtenção de permissão de uso de informaçōes; levantamento e análise dos requisitos de navegação e análise de custo e benefício. É nesta fase que o modelo conceitual é elaborado, com as informações que estarão disponíveis no hiperdocumento.

Uma vez que o modelo conceitual está pronto, passa-se para a etapa de autoria que consiste das seguintes tarefas: organização das informações (elaboração de um projeto) e criação de um protótipo do hiperdocumento com base no projeto criado. A criação do protótipo compreende a composição dos nós e links. 
A reorganização por sua vez, consiste de um protótipo que vai ser reorganizado de forma a atender os problemas encontrados na etapa de exame. Uma vez reorganizado o hiperdocumento, o mesmo entra no ciclo de melhoria continua até obter o nivel de qualidade desejado. A diferença entre a reorganização com a análise de requisitos, é que na análise não existe nenhum protótipo pronto, enquanto que na reorganização um protótipo já foi feito e também já passou pela etapa de exame.

A etapa de exame é que dá suporte à avaliação de qualidade do hiperdocumento. Como já foi mencionado, para que haja uma avaliação da qualidade, devem ser identificados atributos observáveis para atender a todos os pontos de vistas dos usuários do hiperdocumento, ou seja, os requisitos esperados por usuários e desenvolvedores. Vale ressaltar também que esses requisitos devem ser condizentes com o domínio da aplicação em questão.

Com base nesse ciclo de vida de prototipação evolutiva e sabendo da necessidade de um suporte para a avaliação que pudesse ajudar aos autores de hipermídia, Fortes (1996) propôs então uma avaliação com base na estrutura do hiperdocumento.

Inicialmente, foram estabelecidos alguns requisitos para composição do cenário de desenvolvimento do trabalho. Uma premissa foi de que como todo site é composto por páginas, que podem conter links os quais permitem ao usuário a navegação, a representação de hiperdocumentos pode ser esquematizada conforme Figura 5, na qual as páginas são os nós e a estrutura de ligação entre esses nós (páginas) é o link.

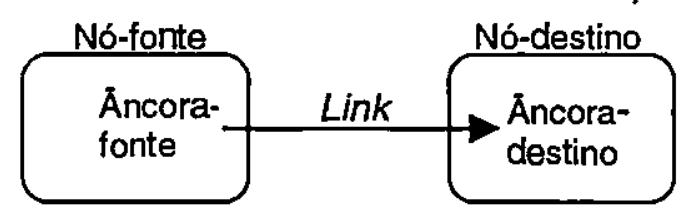

Figura 5. Representação estrutural do elemento Link de hiperdocumento da WWW

A partir desta premissa, a classificação de oito casos de reuso de links proposta por Fortes são descritos a seguir (Fortes, 1996): 


\section{- Caso 0}

A representação estrutural deste caso 0 (vide Figura 6) pode ser interpretada como - links que partem de páginas diferentes ( $A$ e B), possuem rótulos distintos (" $x$ " e " $y$ ") e levam a páginas também distintas (C e D). De fato, uma avaliação desse tipo de link pode ser feita buscando-se por links que não possuem nada em comum com os demais do site, ou seja, nenhum reuso.

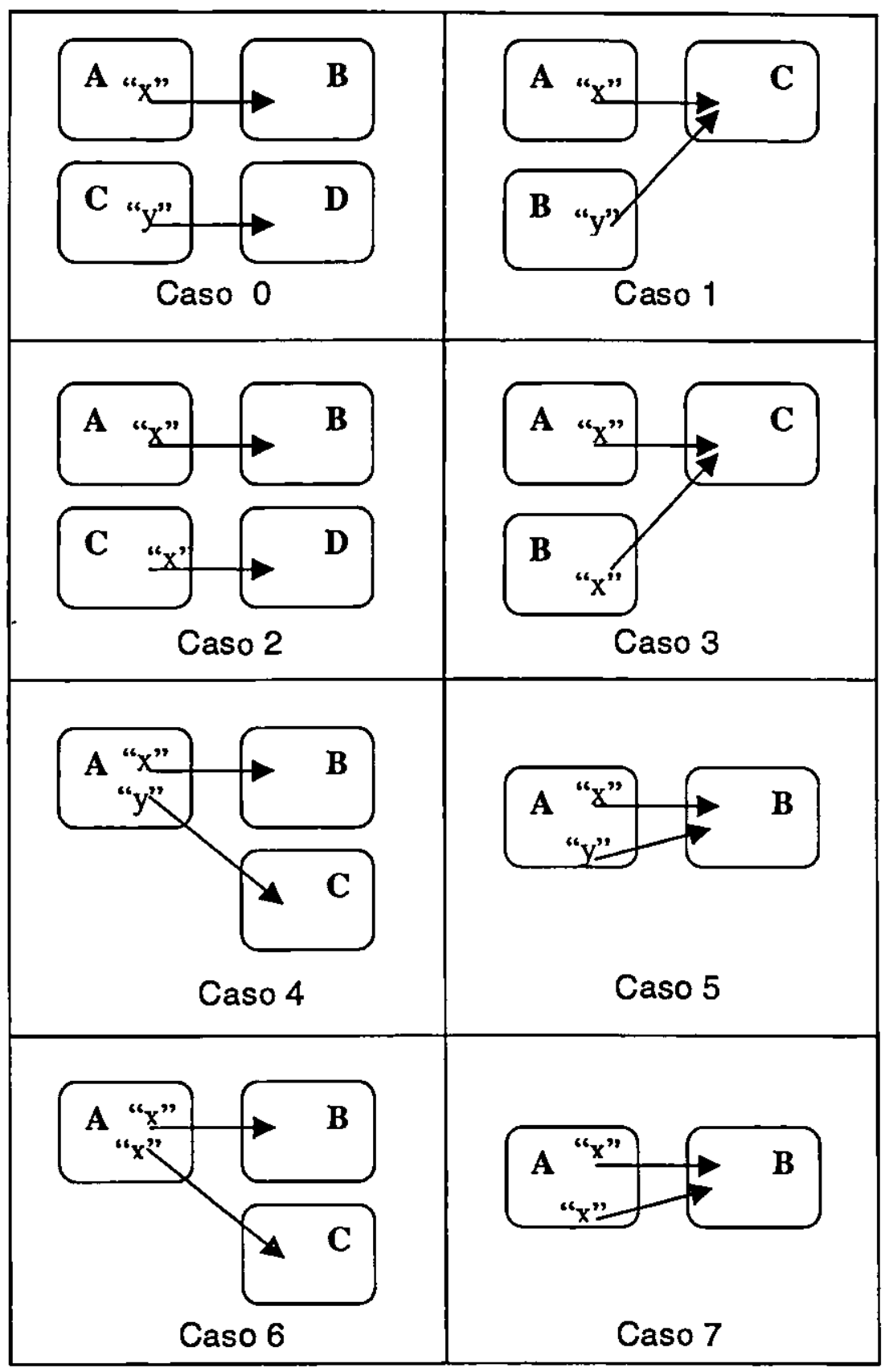

Figura 6. Esquema de Casos de Reuso de componentes de Links (Fortes, 1996) 
- Caso 1

A representação estrutural deste caso 1 (vide Figura 6) pode ser interpretada como - links que partem de páginas diferentes ( $A$ e B), possuem rótulos distintos (" $x$ " e " $y$ "), mas levam a uma mesma página-destino (C). Uma avaliação desse tipo de link pode ser feita buscando-se por links que possuem somente em comum a página-destino.

\section{- Caso 2}

A representação estrutural deste caso 2 (vide Figura 6) pode ser interpretada como - links que partem de páginas diferentes ( $A$ e $B$ ), possuem mesmo rótulo (" $x$ "), que levam a páginas distintas (C e D). Uma avaliação desse tipo de link pode ser feita buscando-se por llnks que possuem somente em comum o rótulo do link.

\section{- Caso 3}

A representação estrutural deste caso 3 (vide Figura 6) pode ser interpretada como - links que partem de páginas diferentes ( $A$ e B), possuem mesmo rótulo (" $x$ ") que levam a uma mesma página-destino (C). Uma avaliação desse tipo de link pode ser feita buscando-se por links que possuem em comum os rótulos de link e as mesmas páginas-destino.

\section{- Caso 4}

A representação estrutural deste caso 4 (vide Figura 6) pode ser interpretada como - links que partem de uma mesma página ( $A)$, possuem rótulos distintos ( $x$ " e " $y$ ") que levam a páginas também distintas $(B$ e $C$ ). Uma avaliação desse tipo de link pode ser feita buscando-se por links que possuem em comum a página-origem dos links, cujos demais elementos (rótulo de link e páginas-destino) sejam distintos.

\section{- Caso 5}

A representação estrutural deste caso 5 (vide Figura 6) pode ser interpretada como - links que partem de uma mesma página (A), possuem rótulos distintos (" $x$ " e " $y$ ") de links que levam para uma mesma página-destino (B). Uma avaliação desse tipo de link pode ser feita buscando-se por links que possuem em comum tanto a página-origem quanto à página-destino dos links, mas com rótulos de links distintos.

\section{- Caso 6}

A representação estrutural deste caso 6 (vide Figura 6) pode ser interpretada como - links que partem de uma mesma página (A), possuem rótulos iguais ( $x$ ") de links em seu conteúdo que levam para páginas-destino distintas (B e C). Uma avaliação desse tipo de link pode ser feita 
buscando-se por links que possuem em comum tanto a página-origem quanto os rótulos de mais de um de seus links, levando a páginas-destino diferentes.

\section{- Caso 7}

A representação estrutural deste caso 7 (vide Figura 6) pode ser interpretada como - links que partem de uma mesma página (A), possuem rótulos iguais (" $x$ ") de links em seu conteúdo que levam a mesma página-destino (B). Uma avaliação desse tipo de link pode ser feita buscandose por links que possuem todos os seus elementos (página-origem, rótulos de seus links e páginas-destino) reutilizados.

Nesta seção, foram apresentados alguns métodos e abordagens que visam à qualidade em hipermídia, independente do domínio em que serão utilizados. Os métodos norteiam os indicativos de qualidade de aplicações hipermídia, seja como produto, seja durante o seu desenvolvimento. A seguir, são apresentados os aspectos relacionados ao domínio educacional, para que um hiperdocumento possua qualidade.

\subsection{Qualidade em Hipermídia Educacional}

A questão da informática na educação é discutida tanto por profissionais da área da informática como por profissionais da área da educação. Qualquer tecnologia que for utilizada na educação deve contar como uma equipe multidisciplinar de forma que atenda os requisitos propostos, pois na realidade nenhum professor precisa se tornar um programador ou expert em ciência da computação. Mas existe sim a necessidade de que os professores avaliem um software educacional (Campos, 1994b).

Mas como avaliar a qualidade se, como já foi discutido, ela é uma medida indireta e também a qualidade depende da pessoa envolvida, pois para cada pessoa o termo qualidade pode tratar-se de requisitos diferentes. No caso do software educacional tem-se como premissa à afirmação feita por Moreira (1987), onde ele considera dois pontos no software educacional, o lado técnico computacional e o lado pedagógico. Para se aplicar a esses diferentes pontos de vista, em sua maioria, as avaliações de hipermídia educacional são feitas através de lista de verificação (checklist).

A proposta de uma lista de verificação elaborada por Campos (1994), indica atributos de qualidade para três perspectivas diferentes, que são:

Autores: pessoas que desenvolvem os hiperdocumentos; 
Leitores: pessoas que irão utilizar o sistema, ou seja, irão navegar pelos nós e links do hiperdocumento; e;

Co-autores: que são os responsáveis pela manutenção dos hiperdocumentos.

A proposta de Campos (1994) é baseada no método proposto por Rocha (1987) para avaliação de qualidade de Software. Por qualidade ser uma medida indireta, os atributos propostos por Campos foram originalmente divididos nas seguintes classes: a) objetivo - propriedades gerais que o produto deve possuir, b) fatores - o que é considerado como qualidade para os pontos de vistas dos diferentes usuários do produto, c) sub-fatores - são decomposições dos fatores que uma vez atingidas atendem a um determinado fator e, d) critérios - definem atributos primitivos a serem avaliados. Assim sendo, é através dos critérios que os fatores podem ser analisados.

Os objetivos de qualidade que Campos (1994) contempla através de sua Lista de Verificação (checklist) são: usabilidade, confiabilidade conceitual e confiabilidade da representação. A usabilidade refere-se a utilização do produto em qualquer etapa do seu desenvolvimento, ou seja, a utilização tanto em sua implementação como na utilização ou manutenção. A confiabilidade conceitual refere-se ao conteúdo da documentação interna e do código fonte do programa, para averiguar se os mesmos atendem as suas especificações. A confiabilidade de representação refere-se à descrição, à organização e à representação da documentação interna e do código fonte, de forma que o programa possa ser manipulado por qualquer pessoa em toda a sua vida útil.

Uma vez definidos os objetivos a serem alcançados, os objetivos foram então decompostos em fatores, sub-fatores e critérios. O Quadro 1 apresenta a decomposição do objetivo confiabilidade de representação em seus fatores, sub-fatores e critérios, o Quadro 2 apresenta os aspectos referentes à confiabilidade conceitual e, finalmente, o Quadro 3 apresenta os aspectos referentes a usabilidade.

Quadro 1. Decomposição feita para atender o objetivo da Confiabilidade de Representação

\begin{tabular}{|l|l|l|}
\hline \multicolumn{1}{|c|}{ Confiabilidade de Representação } \\
\hline Fator & \multicolumn{1}{|c|}{ Sub-Fator } & \multicolumn{1}{c|}{ Critérios } \\
\hline Manipulabilidade & Disponibilidade & $\begin{array}{l}\text { Acessibilidade aos Nós; Existência da Documentação; Qualidade } \\
\text { da Documentação e Organização da Documentação dos Nós }\end{array}$ \\
\hline & Rastreabilidade & Localização e Organização da Documentação \\
\hline Legibilidade & Clareza & $\begin{array}{l}\text { Facilidade de Leitura do Hiperdocumento e Facilidade de } \\
\text { Entendimento da Estrutura }\end{array}$ \\
\hline
\end{tabular}


Quadro 2. Decomposição feita para atender o objetivo da Confiabilidade Conceitual

\begin{tabular}{|l|l|l|}
\hline \multicolumn{2}{|c|}{ Confiabilidade Conceitual } \\
\hline \multirow{3}{*}{ Fator } & \multicolumn{1}{|c|}{ Sub-Fator } & \multicolumn{1}{c|}{ Critérios } \\
\hline \multirow{3}{*}{ Fidedignidade } & Completude & $\begin{array}{l}\text { Completude das Informações Requeridas } \\
\text { pelo Usuário }\end{array}$ \\
\cline { 2 - 3 } & Necessidade & $\begin{array}{l}\text { Necessidade das Informações } \\
\text { Implementadas }\end{array}$ \\
\hline \multirow{2}{*}{ Integridade } & Robustez & Resistência a Aç̃es Inadequadas \\
\cline { 2 - 3 } & Segurança & Privacidade \\
\hline
\end{tabular}

Quadro 3. Decomposição feita para atender o objetivo da Usabilidade

\begin{tabular}{|c|c|c|}
\hline \multicolumn{3}{|c|}{ Whabilidade } \\
\hline Fator & Sub-Fator & \begin{tabular}{|c|} 
Critérios \\
\end{tabular} \\
\hline \multirow[t]{2}{*}{ Manutenibilidade } & Alterabilidade & $\begin{array}{l}\text { Alterabilidade Corretiva; Coerência de } \\
\text { Ligações e Propagação de Modificações }\end{array}$ \\
\hline & Evolutibilidade & Suporte a Versões \\
\hline \multirow[b]{4}{*}{ Operacionabildade } & $\begin{array}{l}\text { Disponibilidade de } \\
\text { Recursos }\end{array}$ & $\begin{array}{l}\text { Ferramenta de Edição de Texto; Ferramenta } \\
\text { de Edição Gráfica; Ferramenta de Edição de } \\
\text { Som e Projeto de Telas }\end{array}$ \\
\hline & Oportunidade & $\begin{array}{l}\text { Eficiência de Autoria; Liberdade para Autoria } \\
\text { e Seleção de Auxílio }\end{array}$ \\
\hline & $\begin{array}{l}\text { Estrutura de Trabalho } \\
\text { Cooperativo }\end{array}$ & $\begin{array}{l}\text { Apoio Trabalho Cooperativo e Suporte a } \\
\text { Comunicação }\end{array}$ \\
\hline & Amenidade de Uso & $\begin{array}{l}\text { Facilidade de Aprendizado; Visualização das } \\
\text { Informações; Informações Sobre os Nós; } \\
\text { Facilidade de Localização Facilidade de } \\
\text { Lembrança; Clareza dos Comandos; Clareza } \\
\text { dos Ícones e Convenções; Estabilidade; } \\
\text { Tutorial para Autoria; Customização; } \\
\text { Documentação; Disponipilidade Funções de } \\
\text { Editoração; Detector de Referência Cega e } \\
\text { Uso de Sinônimos }\end{array}$ \\
\hline \multirow[t]{2}{*}{ Portabilidade } & $\begin{array}{l}\text { Independência de } \\
\text { Ambiente }\end{array}$ & $\begin{array}{l}\text { Independência de Hardware e Independência } \\
\text { de Software }\end{array}$ \\
\hline & Configurabilidade & Adaptação ao Ambiente \\
\hline \multirow[b]{2}{*}{ Suporte à Reutilização } & Modularidade & Composição Modular \\
\hline & $\begin{array}{l}\text { Suporte de Base de } \\
\text { Componentes }\end{array}$ & Adaptabilidade e Localização \\
\hline \multirow{4}{*}{ Eficiência } & $\begin{array}{l}\text { Eficiência de Troca de } \\
\text { Autor/Leitor }\end{array}$ & Tempo de Troca de Modos \\
\hline & $\begin{array}{l}\text { Eficiência de } \\
\text { Armazenamento }\end{array}$ & $\begin{array}{l}\text { Otimização de Armazenamento e } \\
\text { Compressão de Dados }\end{array}$ \\
\hline & $\begin{array}{l}\text { Eficiência de Integração } \\
\text { com Outros Softwares }\end{array}$ & $\begin{array}{l}\text { Capacidade de Importação de Textos; } \\
\text { Capacidade de Uso de Editores de Texto } \\
\text { Externos; Capacidade de Uso de Editores } \\
\text { Gráficos Externos e Capacidade de Uso de } \\
\text { Editores de Som Externos }\end{array}$ \\
\hline & Facilidades Oferecidas & $\begin{array}{l}\text { Diversidade de Informações Representáveis; } \\
\text { Suporte a Visões e Acesso a CD-ROM e } \\
\text { Outros Dispositivos de Armazenamento } \\
\end{array}$ \\
\hline \multirow{2}{*}{ Rentabilidade } & Lucratividade & $\begin{array}{l}\text { Adequação do Sistema ; Preço; Distribuição } \\
\text { do Browser e Taxa de Retorno } \\
\end{array}$ \\
\hline & $\begin{array}{l}\text { Vantagens oferecidas pelo } \\
\text { Vendedor }\end{array}$ & $\begin{array}{l}\text { Direito a Upgrade; Programa de Treinamento } \\
\text { e Suporte }\end{array}$ \\
\hline
\end{tabular}


Campos (1994) propôs uma Lista de Verificação especificamente para hipermídia na educação, Ramos e Mendonça (1991) propuseram uma relação de aspectos a serem observados na avaliação de software educacional independente da tecnologia utilizada. Os critérios ergonômicos propostos podem ser analisados independente da tecnologia utilizada e são eles:

- Sucessão de operações: trata-se da seqüência que o usuário deve percorrer, se a seqüência é flexível conforme o grau de experiência do usuário, se existe uma seqüência lógica que condiz com o que o usuário espera ou se existe uma lógica de operação;

- Linguagem de interação: trata-se do vocabulário utilizado no software. Este vocabulário deve ser de fácil compreensão pelos usuários. Os ícones são uma forma de linguagem de interação e, se não houver ambigüidades, podem ser uma forma bastante interessante para expressar um conceito a partir de uma imagem de fácil memorização a partir de analogias.

- Tempo de resposta: trata-se do tempo necessário para dar uma resposta ao usuário. Segundo resultados apontados pela Psicologia, o tempo de resposta ideal é de 2 a 6 segundos, sendo que 2 segundos é o tempo de resposta numa conversação entre duas pessoas.

- Tratamento de erros: refere-se a como os erros devem ser tratados para que interfira o mínimo possivel no aprendizado. Há uma unanimidade de opiniões sobre o fato de que uma vez cometido um erro, o mesmo deve ser assinalado imediatamente ou no menor espaço de tempo possfvel. E ao cometer um erro, o usuário deve ter a opção de repetir a tarefa executada de forma a corrigir o erro cometido.

\subsection{Considerações Finais}

Neste capitulo foram informalmente definidos os conceitos: qualidade, qualidade de software e métricas, que são a base para o entendimento deste trabalho. Foi observado também que as medidas indiretas não são facilmente derivadas em medidas diretas, que também depende da pessoa que está julgando o produto, bem como de seus objetivos.

Com este capitulo pode-se concluir que não existe uma definição consolidada de qualidade em hipermidia. Os esforços para obtenção de qualquer indicio de qualidade são feitos através de métodos, abordagens e métricas propostas. Assim como as métricas de software, as métricas de hipermídia devem ser aplicadas para obter algum indicativo de qualidade, cabendo ao autor decidir se o resultado fornecido deve ser considerado. As aplicaçōes hipermídia vêm crescendo muito ultimamente e tem atingido domínios bem diferentes. Em todos os domínios, porém, é também necessário se garantir um mínimo de qualidade. 
Outro fator relevante, similar ao considerado para software em geral, é de que ao se abordar mais especificamente um domínio a que se destina a aplicaçāo hipermídia, busca-se uma melhor eficácia dos seus indicativos de qualidade. Dessa forma, ao se restringir também o domínio, visa-se identificar os critérios de qualidade que sejam mais claramente estabelecidos.

Dessa maneira, o próximo capítulo apresenta uma proposta para avaliaçāo estrutural para hipermidia educacional. 


\subsection{Consideraçōes Iniciais}

Qualidade tem sido identificada como uma área de pesquisa de grande importância e como tal, em hipermídia também deve ser considerada. A área de aplicaçāo de hipermídia educacional, por sua vez, se apresenta como uma inovação que pode efetivamente servir de auxilio ao cenário de ensino-estudo-aprendizado. Para a identificação de indicativos de qualidade em hipermídia educacional, é necessário que tenha-se em mente algum critério de avaliação. Dessa forma, neste capítulo é apresentada uma proposta para avaliação estrutural para hipermídia educacional.

Para a avaliação estrutural de hipermídia educacional, considerou-se que: a) uma aplicação hipermídia educacional possui duas perspectivas de avaliaçăo, a técnico-computacional e a pedagógica; b) uma análise de atributos observáveis possibilita uma abordagem inicial para que indicativos de qualidade sejam identificados; e c) é necessária uma simplificação da avaliação estrutural proposta por Fortes (Fortes, 1996), (Fortes et al., 1997), (Fortes \& Nicoletti, 1999) de maneira a fornecer uma semântica adequada ao domínio de material didático, bem como facilitar sua utilização como indicativo de qualidade.

Na Seção 4.2 é apresentada a proposta da avaliação estrutural, mostrando qual a motivação dessa avaliação, assim como os critérios considerados. Na Seção 4.3, as considerações finais sobre a proposta da avaliação estrutural são apresentadas.

\subsection{Avaliação Estrutural em Hipermídia Educacional}

A partir dos estudos realizados na revisão bibliográfica apresentada nos capítulos anteriores foi possível concluir que as aplicaçōes hipermídia educacionais podem trazer progressos para a área pedagógica. Mas que essas hipermídia educacionais, como qualquer software, devem possuir qualidade.

Hatzmanikatis et al. (1995) afirmam que não existe uma definiçăo completa de qualidade de hiperdocumento, $\theta$ os métodos $e$ ferramentas que poderiam ajudar na avaliaçăo estão em estágios primitivos com relação ao auxílio efetivo que deveriam oferecer. Porém, observam que paradigmas úteis e mais adequados para a avaliação de hiperdocumentos podem surgir a partir da experiência prática nas áreas de Engenharia de Software e de Métricas de Software. 
A partir da revisão estudada foi visto também que as métricas são de extrema importância para identificar o grau de qualidade que o produto ou processo possui, ou para identificar possíveis problemas de qualidade $\theta$ dessa maneira concluir que existe falta de qualidade. As métricas abordadas para hipermídia (de domínio geral de conhecimento) foram propostas tendo como objetivo avaliar, em sua maioria, a usabilidade do produto (Botafogo et al., 1992) (Hatzmanikatis et al., 1995) (Yamada et al., 1995) (Garzotto \& Paolini, 1999). Neste trabalho, a usabilidade também foi considerada como a característica qualitativa de uma aplicação hipermídia educacional. Segundo Squires e. Preece (1996), a usabilidade representa uma parcela relevante no processo de avaliação do software educacional.

Considerou-se que a meta de se certificar quanto ao aprendizado (do usuário aluno) obtido durante a navegação pelo hiperdocumento é uma questão extremamente importante, mas, seu escopo pedagógico não nos habilita avaliar. Dessa forma, avaliou-se o lado técnicocomputacional sugerido por Moreira (1987) e alguns dos critérios propostos nas visões dos autores e co-autores sugeridas por Campos (1994).

É fato que toda aplicação hipermídia, independentemente de domínio, possui problemas inerentes que podem afetar sua qualidade: sobrecarga cognitiva, desorientação do usuário e falta de coerência. A área educacional, entretanto, além desses problemas, conta com outros fatores que devem ser considerados na sua avaliação, por exemplo: questões culturais, éticas, psico-pedagógicas e filosóficas (Campos, 1994).

Campos, em seu trabalho, elaborou uma lista de verificação (checklist) para avaliação de hipermidia educacional, na qual sugere os atributos de qualidade sob três perspectivas diferentes. As perspectivas, como citado anteriormente, são identificadas como: de autores, de leitores e de co-autores (Campos, 1994).

Novamente, sabe-se que a perspectiva dos leitores é um alvo primordial da aplicação hipermídia educacional, mas como essa perspectiva se refere mais ao escopo pedagógico, foi deixado para os especialistas da área avaliarem e, portanto, esse aspecto não será focalizado neste trabalho. Este trabalho visa dar indicativos de qualidade segundo as perspectivas dos usuários autor e co-autor, fazendo com que alguns critérios propostos sejam verificados automaticamente. 
A proposta de avaliação neste trabalho então é proporcionar de forma automática, que os atributos de qualidade relaçionados à estrutura de um hipermidia educacional sejam coletados. Esta proposta tem como base à avaliação estrutural de hiperdocumentos de Fortes (1996) combinada com atributos da lista de verificação sugerida por Campos (1994) e com os atributos sugeridos por Ramos \& Mendonça (1991). Esses atributos foram selecionados de forma que pudessem ser identificados como adequados para serem processados automaticamerite a partir da avaliação estrutural de Fortes. Tais atributos foram então investigados e são descritos a seguir.

Um dos objetivos de qualidade focalizados por Campos (1994) e adotado também neste trabalho é a usabilidade. Usabilidade pode ser definida como todas as possiveis formas de utilização de um sistema, ou seja, o esforço para aprender, operar, preparar a entrada e interpretar a saida de um programa (McCall et al., 1977). Na Seção 3.5, o Quadro 3 apresentou uma lista com todos os fatores decompostos a partir do objetivo usabilidade. Em função da meta focalizada ser a usabilidade do aplicativo hipermidia educacional, os fatores de qualidade de hipermídia investigados foram manutenibilidade, operacionalidade e suporte à reutilização, que são descritos a seguir:

- Manutenibilidade: característica observada após o sistema ter sido definido, desenvolvido e aceito como operacional, e existe a necessidade de alteraçöes. Alterabilidade é o sub-fator que interessa, uma vez que significa o quão facilmente o sistema permite fazer uma modificação. Por sua vez, este sub-fator conta com o critério coerência das ligaçöes, que considera as referências incoerentes causadas por exclusão ou modificação de um nó.

- Operacionalidade: característica de uma aplicação hipermídia ser oportuna e amena ao uso durante seu tempo de utilização. O sub-fator investigado foi amenidade de uso (refere-se aos recursos que possibilitam satisfação e confiança ao usuário oferecido pela aplicação hipermídia) e os critérios observados foram: facilidade de localização, detector de referência cega, visualização de informaçöes e uso de sinônimos. Facilidade de localização significa o sistema não permitir nós "cegos" ou nós que conduzam a ligaçōes erradas. Detector de referência cega significa o sistema oferecer uma lista com as ligações cujos nós destinos não foram efetivamente criados. Visualização de informações é a preocupação com a existência de mapas globais $\mathrm{e}$ índices no hiperdocumento. $\mathrm{E}$ uso de sinônimos, por sua vez, indica se o sistema permite ao autor definir sinônimos para nós, ligações e termos de referência. 
- Suporte à reutilização: característica que uma aplicação hipermídia possui ao permitir a criação de estruturas de nós candidatos à reutilização. $O$ sub-fator visto foi modularidade, que é a característica do sistema de autoria permitir a criação de estruturas de nós que possam ser considerados para reutilização de forma independente de outros nós. Já o critério analisado foi composição modular que é definido somente com uma questāo: "Um nó pode ser facilmente reutilizado de forma independente de outros nós?".

Os critérios descritos foram escolhidos por tratarem especificamente de características relacionadas com a parte estrutural do hiperdocumento. $\mathrm{E}$ a abordagem proposta é de além de se utilizar a Lista de Verificação de Campos (1994) para analisar esses critérios, o processo de avaliação da qualidade seja agilizado com o suporte de uma ferramenta que automaticamente auxlliasse a análise e fornecesse, de forma clara, indicadores das características relacionadas com aqueles critérios de qualidade.

Para a análise estrutural da aplicação hipermídia educacional foi então utilizada uma análise relacional de reuso de links. Segundo Garzotto (1995), o reuso visa à utilização de objetos e operaçōes em diferentes contextos e para diferentes propósitos. Algumas razões pelas quais 0 reuso deve ser utilizado são: promover consisténcia - forma de tratamento de elemertos com conceitos similares ou distintos; previsibilidade - facilidade do usuário de prever um resultado de uma operação, diminuindo a sobrecarga cognitlva e apresentar o material sob diferentes perspectivas e pontos de vista, enriquecendo a aplicação e facilidade - grau de facilidade dos usuários acessarem as informações e o grau de entendimento das operações necessárias para conseguir este acesso. Além disso, o reuso possui outras vantagens, tais como: reduzlr erros, esforços de desenvolvimento e minimizar espaço físico (Garzotto et al., 1996) (Thackaberry \& Rada, 1998) (Nanard et al., 1998).

Como Fortes (1996) identificou a existência dos casos de reuso de links para qualquer tipo de domínio (vide Seção 3.4. Figura 6), neste trabalho os casos foram analisados especificamente para o domínio educacional. $O$ objetivo foi o de simplificar a análise para o ponto de vista educacional de forma que o autor pudesse, através de indicativos com mais semântica, melhorar seu site. Assim, a proposta se guiou por meio da investigaçăo, análise do domínio dos recursos utilizados em hlpermídla educacional, nomeação significativa de cada um dos casos propostos por Fortes, no âmbito do domínio de informações relativas ao contexto educacional. Além disso, explorar o que cada caso efetivamente contribui para a qualidade de hipermídia na área educacional. 
A partir da utilização de uma ferramenta DB-LiOS (DataBase - Link Oriented System) (Seraphim, 2000), desenvolvida para avaliar os casos de links propostos por Fortes, analisouse diversos sites educacionais da WWW e os casos foram renomeados de forma a se tornarem mais significativos. Ainda com a preocupação de como esses dados poderiam efetivamente ajudar, de forma esclarecedora, na avaliação de aplicação hipermídia educacional, fol realizada uma análise criteriosa dos significados de cada caso de reuso de links. Dessa forma, e tendo como base à lista de verificação proposta por Campos, foi possível observar que alguns atributos de qualidade propostos não estavam sendo considerados e que poderiam então ser observados com a ajuda dessa análise estrutural.

A seguir, são descritos os oito casos de reuso de links e as respectivas análises voltadas para o domínio educacional:

\section{- Caso 0 - Dependência Browser}

Este caso corresponde aos links que partem de páginas diferentes, possuem rótulos diferentes e levam a páginas-destino também diferentes.

Já com base nos estudos realizados para adequação ao domínio educacional, esse caso " 0 " foi denominado como dependência de browser, ou seja, o usuário necessita dos recursos oferecidos pelo browser para poder continuar a navegação. Também foi observado que quando ocorre este caso, há uma leitura seqüencial do hiperdocumento e na maioria das vezes esses links levam a um nó terminal, ou seja a partir do qual não existem mais links disponiveis.

Os links pertencentes ao caso "0" são unidirecionais e devem ser utilizados quando a página muda de endereço e deseja-se deixar um link informando o novo endereço ou, quando a página é construída com frames, significando que o usuário tem as opções do frame ou não.

De maneira geral, esse caso deve ser evitado. $\mathrm{Na}$ existência de muitos casos desse tipo, o hiperdocumento em HTML (HyperText Markup Language) deve ser revisto, pois pode significar falta de qualidade. Sobre a dependência de browser, o trabalho de Stotts et al. (1992) é uma das melhores fontes de pesquisa.

Embora essa análise sirva para qualquer tipo de hiperdocumento, este caso de link agrava nos educacionais, pois reflete diretamente no sub-fator de qualidade amenidade de uso, que se refere aos recursos que possibilitam satisfação e confiança ao usuário oferecidos pela aplicação. Mesmo que esse caso possibilite uma leitura seqüencial, existe a dependência de outros recursos que podem ser facilmente adaptados ao hiperdocumento e que podem vir a trazer uma qualidade melhor. 


\section{- Caso 1 - Informações Específicas}

Este caso, como já foi definido, corresponde aos links que partem de páginas diferentes, possuem rótulos diferentes e levam à mesma página-destino.

Para adequação ao domínio educacional, com base nos estudos realizados, este caso "1" pode ser analisado de duas maneiras:

1) Trazendo desorientação ao leitor, pois possibilita que através de rótulos (âncoras) diferentes se chegue ao mesmo conteúdo. Nesta situação, este caso deve ser evitado.

2) Quando for usado propositadamente, onde a situação do rótulo levar à observação de diferentes informaçöes no nó-destino. Especificamente no contexto educacional, os autores podem desejar colocar rótulos com conteúdos diferentes para reforçar os conceitos aprendidos e essas diferenças podem surgir, por exemplo, devido à necessidade de concordância no texto contido na página.

Nessa segunda situação, este caso "1" pode ser útil como estratégia didática para apresentação de informações especificas. Este caso de links, do ponto de vista de usabilidade educacional reflete, quando bem utilizado, o critério uso de sinónimos, pois indica que o hiperdocumento permitiu ao autor definição de sinônimos para nós, ligações e termos de referência.

Porém, vale lembrar que se os rótulos forem muito diferentes, pode trazer desorientação ao usuário devido a diversos links levarem ao mesmo destino.

\section{- Caso 2 - Padronização de Links}

Os links pertencentes ao caso "2" partem de páginas diferentes, possuem rótulos iguais e levam a páginas-destino também diferentes.

A principio este caso significa falta de qualidade (inconsistencia dos links), pois os mesmos rótulos levam a páginas-destino diferentes.

Por outro lado, em diversos materiais de hipermidia educacional foram encontradas várias situações de boa utilização para este caso. Uma forma de utilizaçāo seria a leitura seqüencial, ou seja, o autor utiliza este caso para guiar o estudante por um roteiro específico (por exemplo, por meio do rótulo: "Próxima página"). Outra forma de utilização seria a palavra exemplo, onde vários temas têm seus próprios exemplos e, portanto significam temas e exemplos diferentes, com seus próprios contextos de informação, mas com o mesmo rótulo de link. Outra forma facilmente encontrada é no caso de slides disponíveis ra WMW, contendo os botões back e next das páginas. Dessa forma, tais tipos de utilização do caso 2 indicam uma padronização de links e uma diminuição na sobrecarga cognitiva pois uma vez que os usuários estejam acostumados com os links, eles também estão acostumados com o tjpo de conteúdo que irão encontrar ao acessarem esses links. 
De certa forma, este caso de links afeta o sub-fator de modularidade, que é a característica do sistema de autoria permitir a criação de estruturas de nós que possam ser considerados para reutilização de forma independente de outros nós. Assim, o critério de composição modular foi observado pois o rótulo de link foi reutilizado de forma a possibilitar que módulos (nós independentes) de informação fossem acessados durante a navegação de forma padronizada.

\section{- Caso 3 - Reforço ao Aluno}

Este caso " 3 " pode ser interpretado como os links que partem de páginas diferentes, possuem rótulos iguais e levam a mesma página-destino.

Em qualquer hipermídia, incluindo o educacional, este caso é sempre considerado de boa qualidade. Quanto maior sua incidência, melhor estrutura o hiperdocumento terá.

$\mathrm{Na}$ aplicaçāo hipermídia educacional, este caso " 3 " representa a existência de um tópico que deve ser sempre relembrado, no decorrer do aprendizado. Isso pode facilitar muitas vezes o processo de navegação do estudante. Além disso, nem sempre este caso será visto como reforço ao aluno, pois pode significar também uma uniformidade de termos nas palavras utilizadas como links nos hiperdocumentos. Alguns exemplos desses rótulos comumente utilizados são: "retorno à página principal", "e-mail para webmaster", "comentários sobre a página", "ir para o topo da página". Ou seja, sua utilização reflete links genéricos do hiperdocumento, que em material educacional, deve ter a mesma concepção.

Neste âmbito, este caso de link leva em consideração o critério composição modular. O que significa que a reutilização das páginas e links pode ser feita e a determinação dos nomes dos links deve possuir uma padronização.

\section{- Caso 4-Índices}

A representaçäo estrutural do caso " 4 " corresponde aos links que partem de uma mesma página, possuem rótulos diferentes e levam a páginas-destino diferentes.

Embora, quanto maior a incidência deste caso signifique que houve pouca reutilizaçāo dos objetos, este caso " 4 " significa que existem diversos índices, que facilitam 0 usuário a encontrar a informação que busca.

Nos estudos feitos, foi observada uma grande incidência deste caso "4" que se refere a índices, que se assemelham à escrita em papel, o que significa que o usuário já está habituado com seu uso. No caso da aplicação hipermídia educacional, considerou-se que os links de caso "4", na situação de índices, podem trazer facilidades para o aprendizado.

O critério que se enquadra a este caso de links é a visualização de informação, no qual existe a preocupação com a necessidade de índices nos hiperdocumentos de maneira facilitar a utilização do sistema. 


\section{- Caso 5 - Redundância de Informações}

O caso 5 significa que os links partem de uma mesma página, possuem rótulos diferentes e levam a uma mesma página-destino.

Com base nos estudos realizados para adequação ao domínio educacional, este caso " 5 " deve ser evitado por trazer aborrecimentos ao usuário que na mesma página conta com links distintos que podem levá-lo a obter a mesma informação.

No caso de softwares educacionais pode significar uma ilustração ou reforço de conteúdo da matéria sobre enfoques diferentes. Mesmo assim, observa-se que pode trazer desorientaçăo ao usuário e sobrecarga cognitiva, devido à redundância das informaçōes.

Levando em conta os aspectos educacionais, este caso de link atende o critério uso de sinônimo. Onde o uso de sinônimos nos links é permitido desde que seja utilizado adequadamente.

$\mathrm{Na}$ maioria dos estudos realizados, foram encontrados problemas no hiperdocumento que deveriam ser revistos, um caso típico de utilização deste caso " 5 " foi encontrado quando, o link que levava ao e-mail de um professor para dúvidas era referenciado, hora com este rótulo (email para dúvidas) e hora somente pelo nome do professor. Na realidade, para se analisar esse caso, deve-se ter em mente que o contexto apresentado ao aluno seja suficientemente claro.

\section{- Caso 6-Palavras Significativas}

O caso 6 representa os links que partem de uma mesma página, possuem os rótulos iguais e levam a páginas-destino diferentes.

Com base nos estudos realizados para adequaçăo ao domínio educacional, este caso " 6 " deve ser empregado quando for o caso de palavras significativas e exista um padrão adotado. Muitas vezes, essa situaçăo acontece por se tratar de textos transcritos de material impresso no qual existe uma padronizaçăo de termos para evitar uma sobrecarga de termos diferentes. Por outro lado, palavras como "Clique $e^{4}$ Aqui" não são significativas $\theta$ devem ser evitadas, pois levam a conteúdos diferentes e aumentam a sobrecarga cognitiva do usuário, pois o mesmo não saberá facilmente o tipo de informaçăo que encontrará em um link com este rótulo, e dificilmente se recordará novamente dos caminhos navegados para obter aquela informação. No contexto educacional foi verificado que palavras como "Exemplo", "llustração", "Exercícios" são bastante utilizadas como rótulos de links em uma mesma página, por se tratarem de palavras bastante significativas no domínio didático e dessa forma, nāo apresentam problemas,

\footnotetext{
${ }^{4}$ Palavras como clique e clicar serão utilizadas neste trabalho se referindo a ação causada ao pressionar o botão do mouse.
} 
pois em geral o conteúdo ao redor de tais rótulos apresenta o contexto no qual tal link está inserido. Além disso, os exemplos, ilustraçōes ou exercícios levam mesmo a contextos diferentes, pois tratam de partes distintas da mesma matéria. Um outro aspecto positivo deste caso de palavras significativas é que os usuários vão se habituando a essias palavras e ao tipo de conteúdo que irão encontrar quando se tratar desses links.

Este caso reflete dois critérios: composição modular e uso de sinônimos. Pois da mesma maneira que é permitida a reutilização de links: nas palavras significativas "Exemplo", "llustração" e "Exercícios", é permitido o uso de sinónimos nos links para evitar uma sobrecarga cognitiva, que acontece ao utilizarmos palavras como "Clique aqui", palavra não significativa.

\section{- Caso 7 - Ícones}

O caso 7 representa links que partem de uma mesma página; que possuem rótulos iguais e que levam a uma mesma página-destino.

Com base nos estudos realizados para adequação ao domínio educacional, este caso "7" deve ser analisado criteriosamente, pois pode trazer inconsistência à aplicação hipermídia educacional. No caso de uma página muito extensa de hiperdocumento, para melhor orientar o usuário existe a necessidade desse tipo de reuso de links e dessa maneira, o mesmo deve ser adotado, significando um ponto de navegação ao qual pode ser rapidamente revisitado, mas de forma que não interrompa ou desvie a atenção da leitura do conteúdo propriamente dito. Dessa forma, podem ser utilizados como ícones (símbolo que tem um significado próprio, mas que seja independente do contexto da leitura da página). Caso contrário, esse tipo de reuso pode fazer com que a leitura fique confusa e atrapalhe o usuário. Do ponto de vista educacional, não foi encontrada grande incidência deste caso, mas cabe ao autor avaliar se realmente há a necessidade deste tipo de reuso. Este caso não é considerado um reforço da matéria ao aluno, pois os casos analisados supõem estar apresentando um conteúdo de matéria e uma fez já tendo um link para reforço nāo há necessidade de sempre repeti-lo.

Com os estudos feltos, notou-se a importância na boa utilização dos ícones, pois o ícone pode expressar um conceito a partir de uma imagem de fácil memorizaçāo a partir de analogias. Desta maneira o critério linguagem de interação suporta este caso.

\subsection{Considerações Finais}

Neste capítulo foi apresentado uma definiçāo da semântica de casos de reuso de links que podem auxiliar na avaliação de uma aplicação hipermídia educacional. Além disso, foram descritos os conceitos subjacentes de reuso e alguns critérios propostos que podem auxiliar a avaliação de sua qualidade. 
Considerando as propostas existentes para o domínio educacional, os casos podem se enquadrar nos seguintes critérios:

- Informaçōes Espeçíficas (caso 1) e Redundância de Informaçōes (caso 5) e.Palavras Significativas (cașo 6) que se enquadram no atributo uso de sinónimos. Mostrando que as ligaçōes utilizam esse atributo, ou no caso que não utilizam (Palavras Significativas) deveria ser feita uma melhor análise para que esse atributo fosse utilizado a fim de melhorar o hiperdocumento.

- Padronização de Links (2), Reforço ao Aluno (3) e Palavras Significativas (caso 6) quie se enquadram no atributo composição modular, que se refere ao reuso de nós,e links.

- Dependêncla de Browser (0) se enquadra no sub-fator amenidade de uso, que propõe recursos que facilitem a navegação.

- Índices (4) se enquadram no critério de visualização de informação, que sugere a existência de índices ou mapas globais no hiperdocumento.

- Os Ícones (caso 7) podem se enquadrar no critério linguagem de interação proposto por Ramos \& Mendonça (1991), no qual os ícones são citados como meios mais fáceis de memorização à memória bumana, e deve ser bastante utilizado nas aplicações hipermídia, mas de maneira que não se torne ambíguo, ou seja, um mesmo ícone não deve ter significados diferentes.

Os demais atributos.descritos e que não podem ser obtidos automaticamente pela classificação dos casos serão obtidos através de outras indicaçōes que serão fornecidas pela ferramenta DB-LiOS ${ }^{E}$. Por exemplo, a ferramenta apresenta a contagem dos tipos de páginas existentes no site, que seriam: mortas (páginas que não existem no site), timeout (o tempo de espera do crawler foi ultrapassado), desconhecidas (o HTTP retoma um código de erro diferente de 200), não encontradas, (o processo de classificação foi interrompido) e boas. Esta contagem dos tipos de páginas existentes foi denominada Comportamento das Páginas. Dessa forma, ao verificar-se as páginas mortas e não encontradas, os atributos de coerência de ligaçōes, facilidade de localização e detector de referência cega podem ser satisfeitos.

O Quadro 4 apresenta, de forma resumida, os critérios de qualidade que foram automatizados pela ferramenta desenvolvida (a ser descrita no próximo capítulo) e que auxiliam na avaliaçāo de uma aplicação hipermídia educacional. 
Quadro 4. Resumo dos critérios de qualidade analisados

\begin{tabular}{|c|c|}
\hline 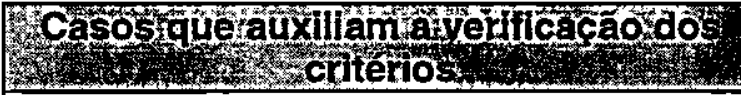 & 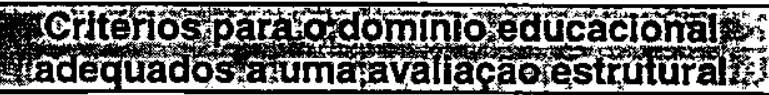 \\
\hline Caso 0 (Dependência de browser) & Amenidade de Uso \\
\hline Caso 1 (Informaçōes Específicas) & Uso de Sinônimos \\
\hline Caso 2 (Padronização de Links) & Composiçāo Modular \\
\hline Caso 3 (Reforço ao Aluno) & Composição Modular \\
\hline Caso 4 (Índice) & Visualização de Informação \\
\hline Caso 5 (Redundância de Informaçōes) & Uso de Sinônimos \\
\hline Caso 6 (Palavras Significativas) & Uso de Sinônimos e Composiçāo Modular \\
\hline Caso 7 (Ícones) & Linguagem de Interação \\
\hline Comportamento das Páginas & Coerência das Ligações \\
\hline Comportamento das Páginas & Facilidade de Localização \\
\hline Comportamento das Páginas & Detector de Referência Cega \\
\hline
\end{tabular}

A partir da revisão bibliográfica, pode-se constatar que a análise estrutural de qualidade de hipermídia educacional proposta, de fato atende aos critérios propostos para o domínio educacional. Mas além dos critérios que são atendidos especificamente no dominio educacional, outras pesquisas podem ser complementadas para reforçar a proposta feita por Fortes (1996):

- O caso classificado como Dependência de Browser (caso 0) atende a proposta feita por Stotts et al. (1992), na qual o método reduz a ênfase no browser e destaca a estrutura do hiperdocumento.

- O caso classificado como Reforço ao Aluno (caso 3) atende ao critério de reuso proposto por Garzotto et al. (1996), Thackaberry \& Rada (1998) e Nanard et al. (1998), que propõem o reuso como forma de reduzir erros e esforços de desenvolvimento.

- O caso denominado como Palavras Significativas (caso 6) atende à previsibilidade, proposta por Garzotto et al. (1995).

- O caso denominado Índice (caso 4) atende à facilidade, critério proposto por Garzotto et al. (1995). 
Seguindo a proposta de definiçăo da semântica de casos de reuso de links que auxiliam na avaliação de uma aplicação hipermídia educacional, a ferramenta DB-LiOS ${ }^{E}$ foi desenvolvida. A ferramenta é descrita no próximo capítulo, juntamente com suas funcionalidades e o estudo de caso realizado a partir de sua utilização. 


\section{A Ferramenta DB-LIOS ${ }^{E}$}

\subsection{Considerações Iniciais}

Neste capítulo é apresentada a ferramenta DB-LiOS ${ }^{\mathrm{E}}$, um suporte automático para avaliação estrutural de hipermídia educacional, com base nos critérios propostos no capitulo anterior. Um primeiro objetivo para o desenvolvimento desta ferramenta foi o de simplificar e agilizar a aplicação da avaliação proposta. Observou-se na revisão da literatura que, quando se trata de hipermídia educacional, o instrumento de avaliação mais usado é o checklist. Dependendo da complexidade do questionário para checklist, sua aplicação requer um nivel de grande conhecimento e de detalhes, dispensando um tempo razoável. Dessa forma, a ferramenta implementada visa facilitar a obtenção de alguns critérios de qualidade do ponto de vista técnico-computacional e complementar a aplicação de checklists.

A ferramenta DB-LIOS ${ }^{E}$ desenvolvida, além de fornecer a classificação dos oito casos de reuso de links e também uma análise de cada caso para facilitar o autor quando o mesmo submeter seu site à avaliação, mostra uma classificação com as páginas mortas, não encontradas, timeout, desconhecidas e boas.

A partir de um estudo inicial dos oito casos de reuso de links, foi também possivel fazer uma classificação de páginas. Além das características aqui citadas, a ferramenta apresenta outras características para facilitar a avaliação de um site, tais como: gráfico dos casos de links, dados estatísticos dos sites, conexão a uma base global, onde se pode acessar outros sites disponibilizados e também controle de versão dos sites.

Para a descrição da ferramenta, este capítulo está organizado da seguinte forma: na Sessão 5.2 são abordadas as características da ferramenta DB-LiOS (Seraphim, 2000), que tinha como objetivo automatizar a proposta de Fortes (1996). A ferramenta DB-LiOS ${ }^{\mathrm{E}}$ segue a estrutura proposta por Seraphim, uma vez que é uma extensão daquela, ou seja, acrescenta as especificidades do domínio educacional e auxilia a análise para avaliação de qualidade. $\mathrm{Na}$ Sessão 5.3 é apresentada a ferramenta DB-LiOS ${ }^{E}$ e suas funcionalidades, através da modelagem dinâmica e modelagem funcional. $\mathrm{Na}$ Sessão 5.4 são descritos os estudos de casos e uma avaliação dos resultados obtidos. Finalmente, na Sessão 5.5 são feitas as consideraçōes finais sobre este capítulo. 


\subsection{Características da Ferramenta DB-LiOS}

A ferramenta DB-LiOS foi implementada por Seraphim (2000) com o objetivo de automatizar a classificação de reuso de links de (Fortes, 1996), (Fortes et al. 1997), (Fortes \& Nicoletti, 1999) fazendo com que a avaliação fosse feita de forma fácil e rápida.

DB-LiOS possui dois módulos para realizar os principais processamentos, são eles:

- Extração de links das páginas: esse módulo é composto de um crawler (Koster, 1995) que funciona sobre o protocolo HTTP (Fielding et al., 1999) filtrando os links das páginas do site. O crawler (Cho et al., 1998) é um programa autônomo que navega por todas páginas do site através de seus links. Os crawlers são utilizados para diversos fins (Koster, 1995), por exemplo, na coleta de palavras para formação de catálogos de Search Engine (Pinkerton, 1994) (como vistos em AltaVista, Yahoo, WebCrawler e Excite) e coleta de todos os documentos que formam o site para criar cópias espelhos do site (Silva et al., 1999). O crawler implementado nesta ferramenta percorre as páginas do site, e extrai as páginas-origem, âncoras e páginas-destino referentes ao links encontrados. 0 crawler ao encontrar uma página-destino que aponta para uma página que pertence ao mesmo site adiciona esta página a uma lista de páginas que deverão ser então filtradas posteriormente, e dessa forma todas as páginas de um site são verificadas.

Outro recurso é que o crawler pode avaliar somente um conjunto de páginas, não necessitando avaliar o site todo. Isso significa que ao informar o endereço de um site, o crawler lê somente as páginas que estão neste subdiretório ou abaixo dele.

- Classificação dos links: este processo pode iniciar assim que a extração de links for finalizada. Sua função é classificar os componentes de links (página-origem, âncora e página-destino) em um dos oito casos propostos por Fortes (1996). Essa classificação é feita através de estruturas de índices. Observa-se que a partir das estruturas de índices, qualquer adição de links em uma página ou a adição de uma nova página com links, assim como sua remoção, pode alterar a classificação dos links existentes e mostra, portanto, a complexidade da manutenção dessas informações.

Com a possibilidade de um site ser alterado e consequentemente a classificação no caso de links ser alterada, a ferramenta DB-LiOS considera os freqüentes processos de evolução de um site, que originam mudanças nas suas páginas e em seus links. $E$ por esse motivo foi implementado o controle de versão do site, onde esses controles são assegurados pela definição de um modelo relacional para a base de dados de DB-LiOS (Figura 7). 
A instalação da ferramenta conta com o SGBD (Sistema Gerenciador de Banco de Dados) Paradox, mas a base foi modelada utilizando tipos de dados comuns a todos os SGBDs. Dessa forma, a ferramenta pode ser executada sob qualquer SGBD relacional, por exemplo: Microsoft Access, Interbase e no PostGresQL.

As informações também podem ser disponlbilizadas em dois tipos de bases de dados: a base global e a base local. A Base Local é uma base de dados usada para a filtragem dos links das páginas dos sites e posterior classificação nos casos de reuso destes links. Essa base fica armazenada na máquina na qual a ferramenta foi instalada. Já a Base Global é uma base de dados de versões dos sites, ou seja, recebe as informaçōes que foram transferidas da Base Local. É utilizada para pesquisas dos sites processados pelos usuários cadastrados, utiliza PostgreSQL sobre a plataforma Linux, e é compartilhada por todos os usuários da ferramenta DB-LiOS.

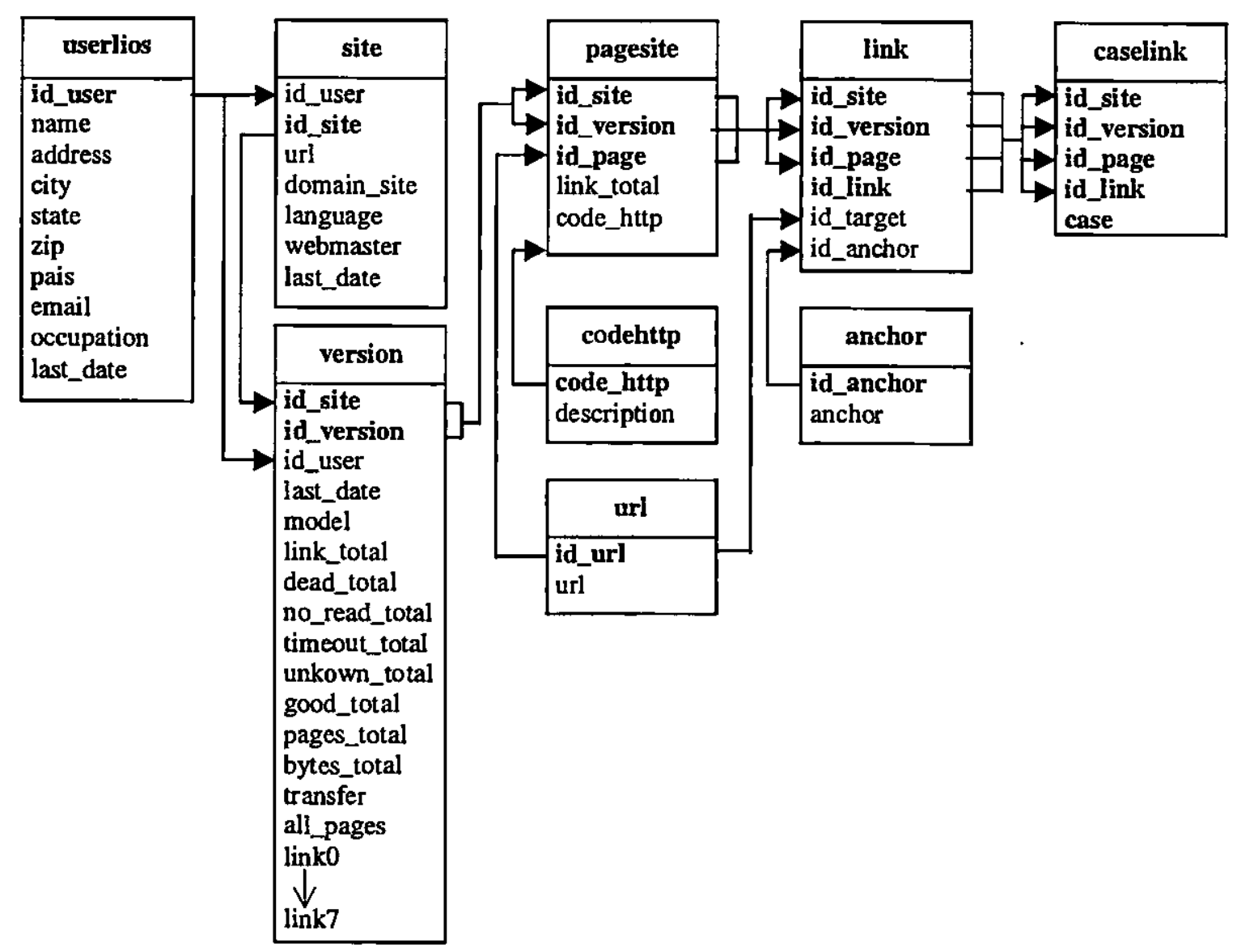

Figura 7. Base de Dados Relacional da DB-LiOS (Seraphim, 2000)

\subsection{Ferramenta DB-LiOS ${ }^{E}$ e suas funções}

A ferramenta $D B-L i O S^{E}$ foi desenvolvida para ambiente Windows, na linguagem de programação Delphi 4.0. Sua arquitetura é esquematizada na Figura 8 , na qual sāo 
apresentados seus três principais módulos funcionais: a) extração de links das páginas crawler, b) classificação dos links; e c) apresentação dos indicativos de qualidade ao autor. 0 primeiro e o segundo módulo são os mesmos descritos na Seção 5.2, por essa ferramenta tratar-se de uma extensão da ferramenta DB-LiOS.

O terceiro módulo é responsável por fornecer indicativos de qualidade ao autor do hiperdocumento através dos oito casos classificados, sob a perspectiva do domínio educacional do material submetido à avaliação. Os critérios foram identificados como: Dependência de Browser (Caso 0), Informações Específicas (Caso 1), Padronização de Links (Caso 2), Reforço ao Aluno (Caso 3), índices (Caso 4), Redundância de Informaçōes (Caso 5), Palavras Significativas (Caso 6) e Ícones (Caso 7). Para atender a todos os critérios desejados foi feita a análise estrutural proposta por Fortes (1996) e um análise de comportamento das páginas, conforme discutido.

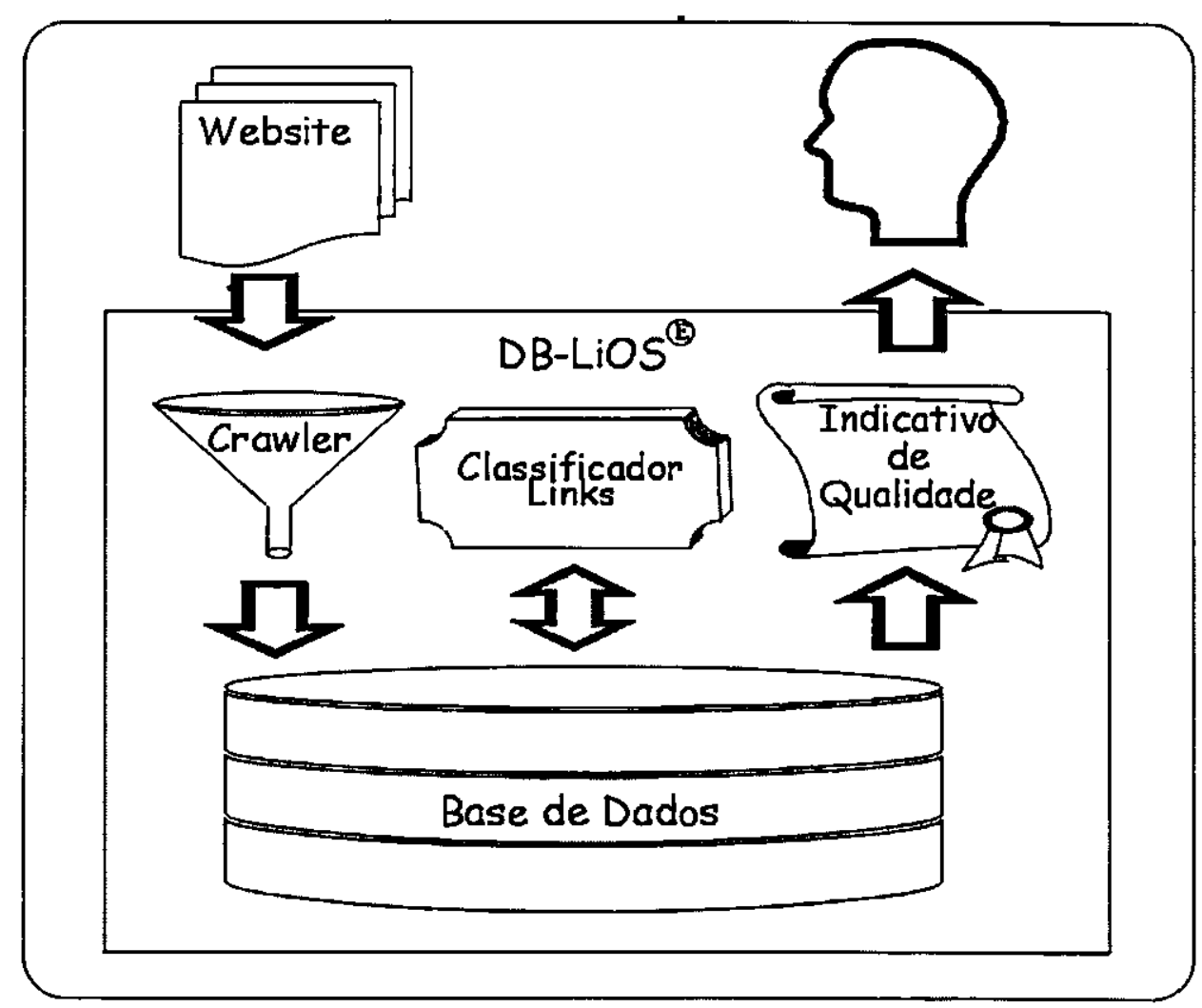

Figura 8. Arquitetura da Ferramenta DB-LiOS ${ }^{E}$

A tela principal da ferramenta ${ }^{D} B-L i O S^{E}$ pode ser visualizada na Figura 9 e a partir desta tela pode-se acessar as informações desejadas. De maneira a facilitar o entendimento da ferramenta, a modelagem especificada é descrita a seguir. 


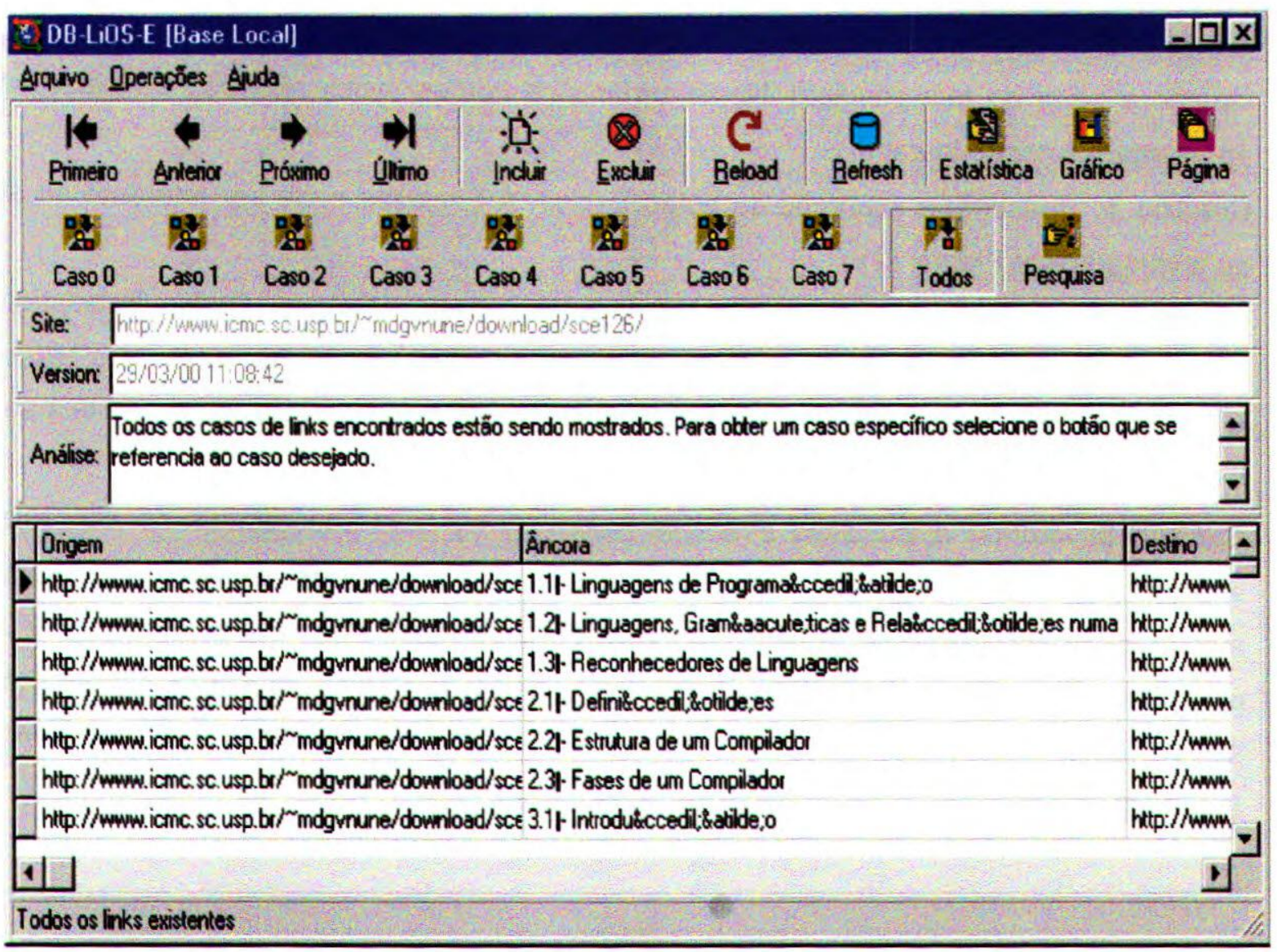

Figura 9.- Tela Principal da Ferramenta DB-LiOS ${ }^{\mathrm{E}}$

\subsubsection{Modelagem Dinâmica - Diagrama de Estados}

A modelagem dinâmica da ferramenta pode ser vista em 5 cenários, de forma a facilitar 0 entendimento das interações e tornar os diagramas de estados mais legiveis de forma que os botões que têm procedimentos iguais ou semelhantes fossem agrupados num mesmo cenário. A seguir, uma visão geral dos cenários são apresentados e na seqüência, os respectivos diagramas de estados:

- Cenário 1: representa a chamada da ferramenta e a conexão para a base global. Assim que a ferramenta estiver ativa, ela faz as seguintes verificações: 1) verifica no ODBC e BDE as configurações, 2) verifica se o usuário está cadastrado na base de dados global e 3) exibe a tela principal a espera de uma interação do usuário. Se a configuração no ODBC/BDE apresentar problemas que não possam ser solucionados automaticamente, a ferramenta aborta sua execução, apresentando uma mensagem de erro ao usuário. A ferramenta também aborta sua execução caso o usuário não consiga estar cadastrado na base de dados global. Os demais procedimentos apresentados no cenário 1 se referem à 
conexão à base global, seu retorno à base local e a possibilidade de alteração nas configurações do sistema e de navegação (vide Figura 10).

- Cenário 2: descreve algumas funcionalidades iniciais (botões) que estão disponíveis ao usuário a partir da tela principal. Neste cenário os botões Incluir, Refresh e Reload são apresentados (vide Figura 11).

- Cenário 3: apresenta a interação do botão Excluir. A Exclusão pode ser referente ao site ou a versão (vide Figura 12).

- Cenário 4: este cenário refere-se aos botões Navegação, Gráfico, Dados Estatísticos, Páginas e Links Mortos. Esses botões possuem interações simples, na qual o usuário seleciona o botão desejado e as informações referentes ao botão são exibidas em tela para consulta (vide Figura 13).

- Cenário 5: informa a interação existente para que os links encontrados no site sejam exibidos. Pode ser selecionado o botão Todos, na qual todos os links existentes no site são mostrados ou pode-se optar por um caso especifico de link. Para casos específicos de link os botões Caso 1, Caso 2, Caso 3, Caso 4, Caso 5, Caso 6 e Caso 7 devem ser selecionados e ao exibir os links pertencentes ao caso selecionado, à análise referente aquele caso específico também é exibida (vide Figura 14).

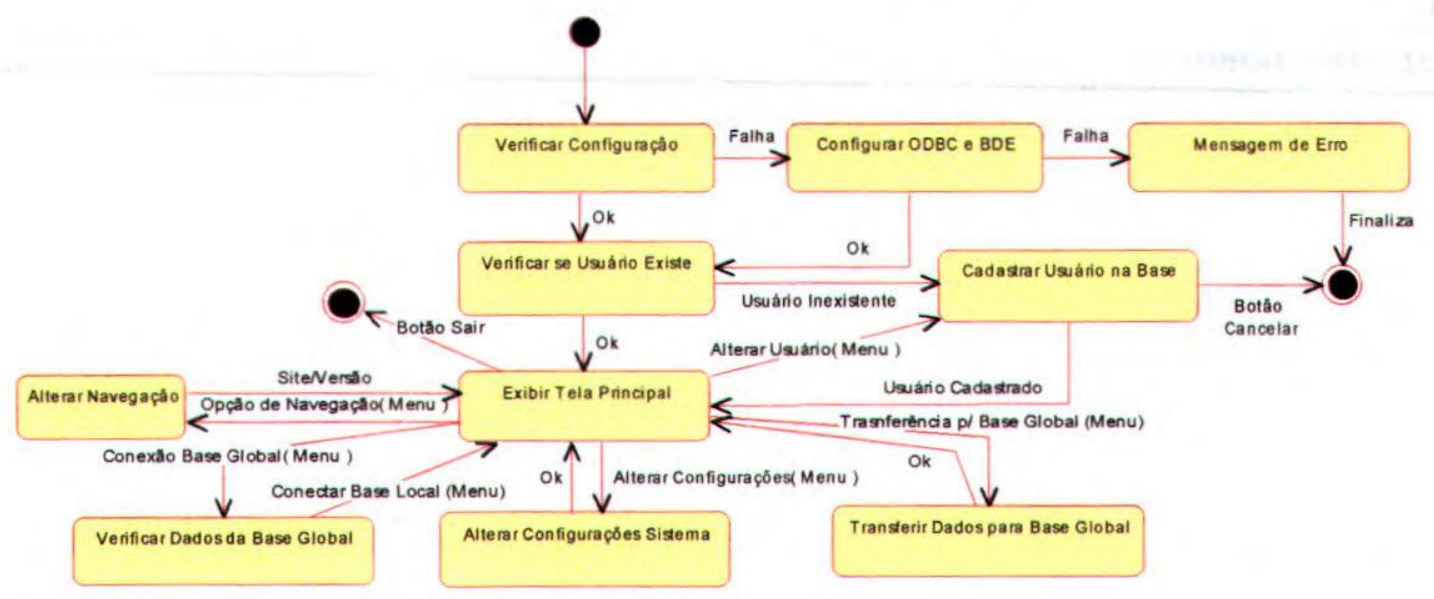

Figura 10. Diagrama de Estados do Cenário 1 


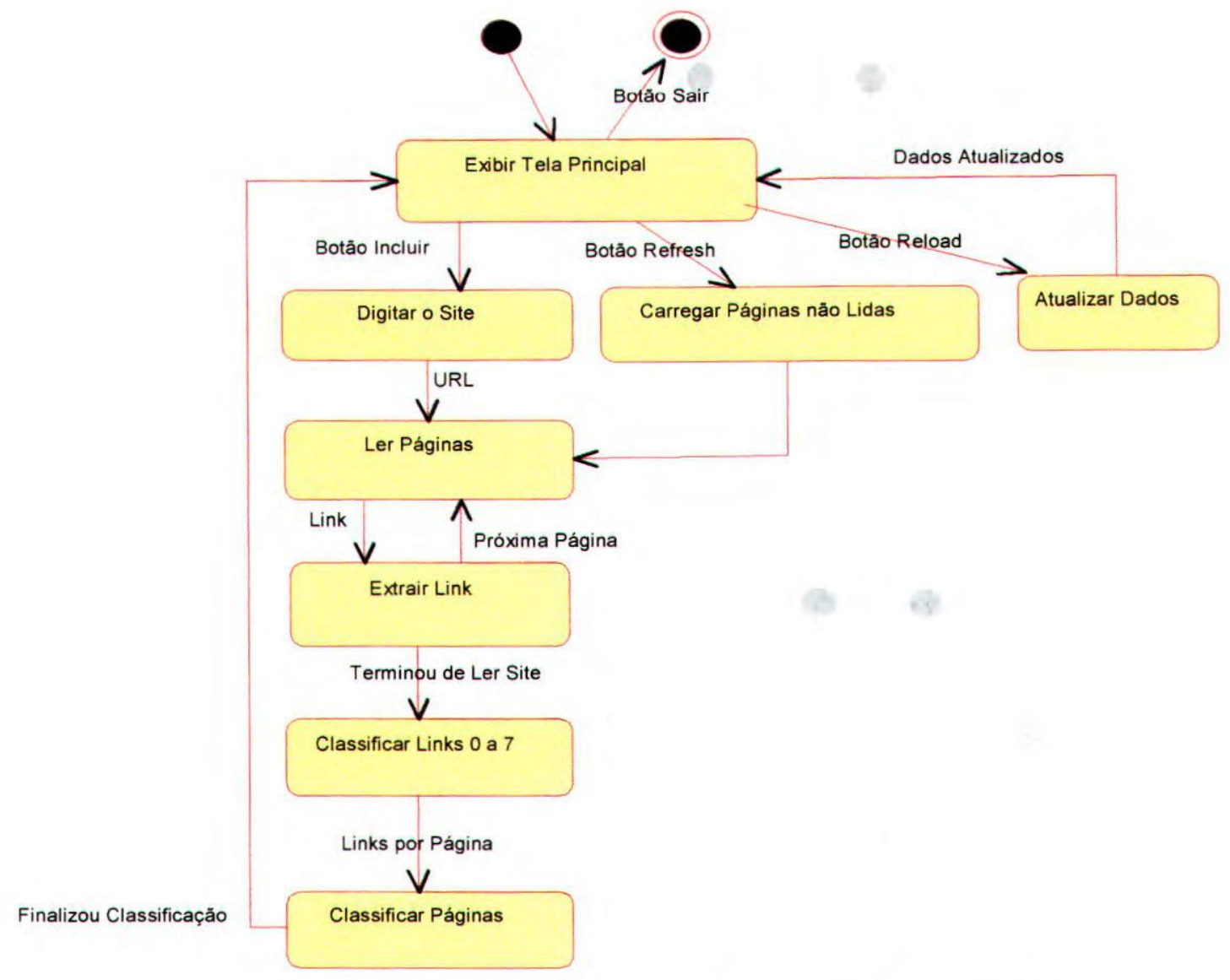

Figura 11. Diagrama de Estados do Cenário 2

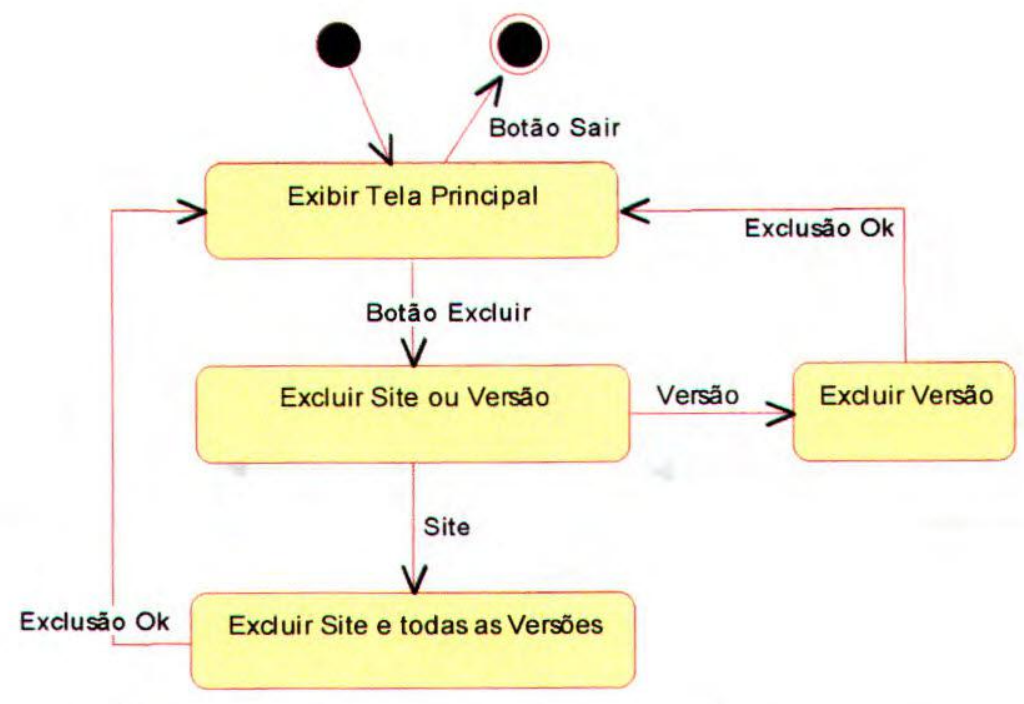

Figura 12. Diagrama de Estados do Cenário 3 


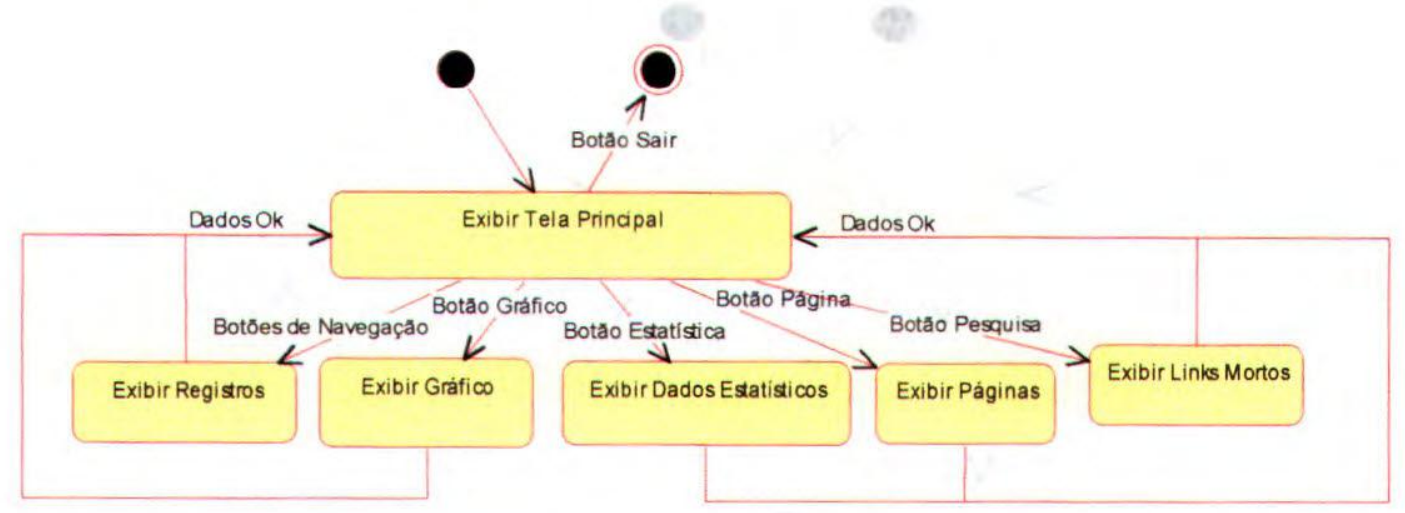

Figura 13. Diagrama de Estados do Cenário 4

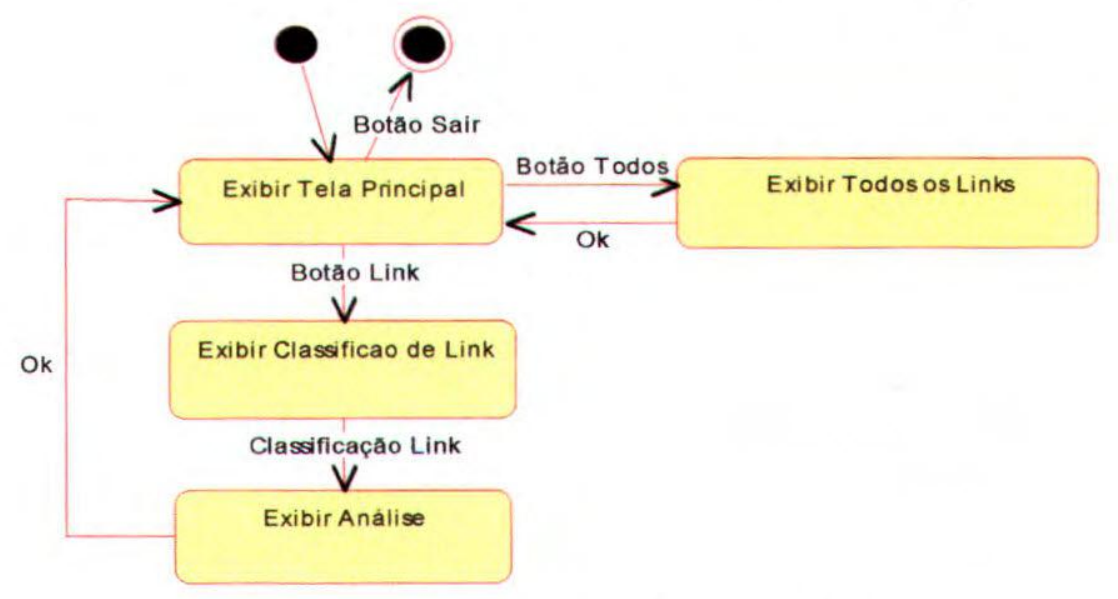

Figura 14. Diagrama de Estados do Cenário 5

\subsubsection{Modelagem Funcional}

As funções de mais alto nivel, especificadas para a ferramenta são apresentadas nos Diagramas de Fluxos de Dados a seguir.

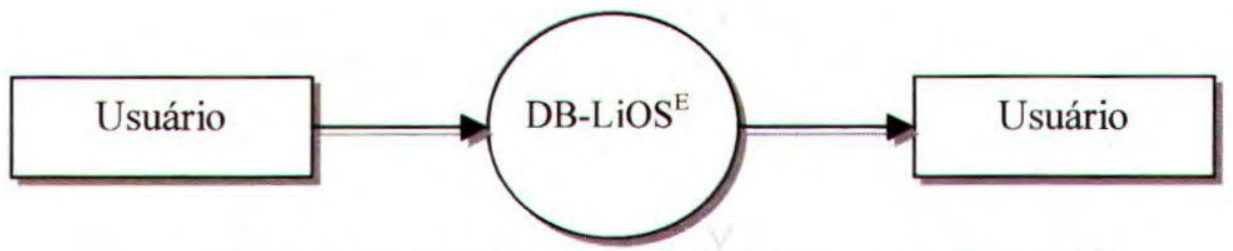

Figura 15. DFD de nível 0 da Ferramenta DB-LiOS ${ }^{E}$ 


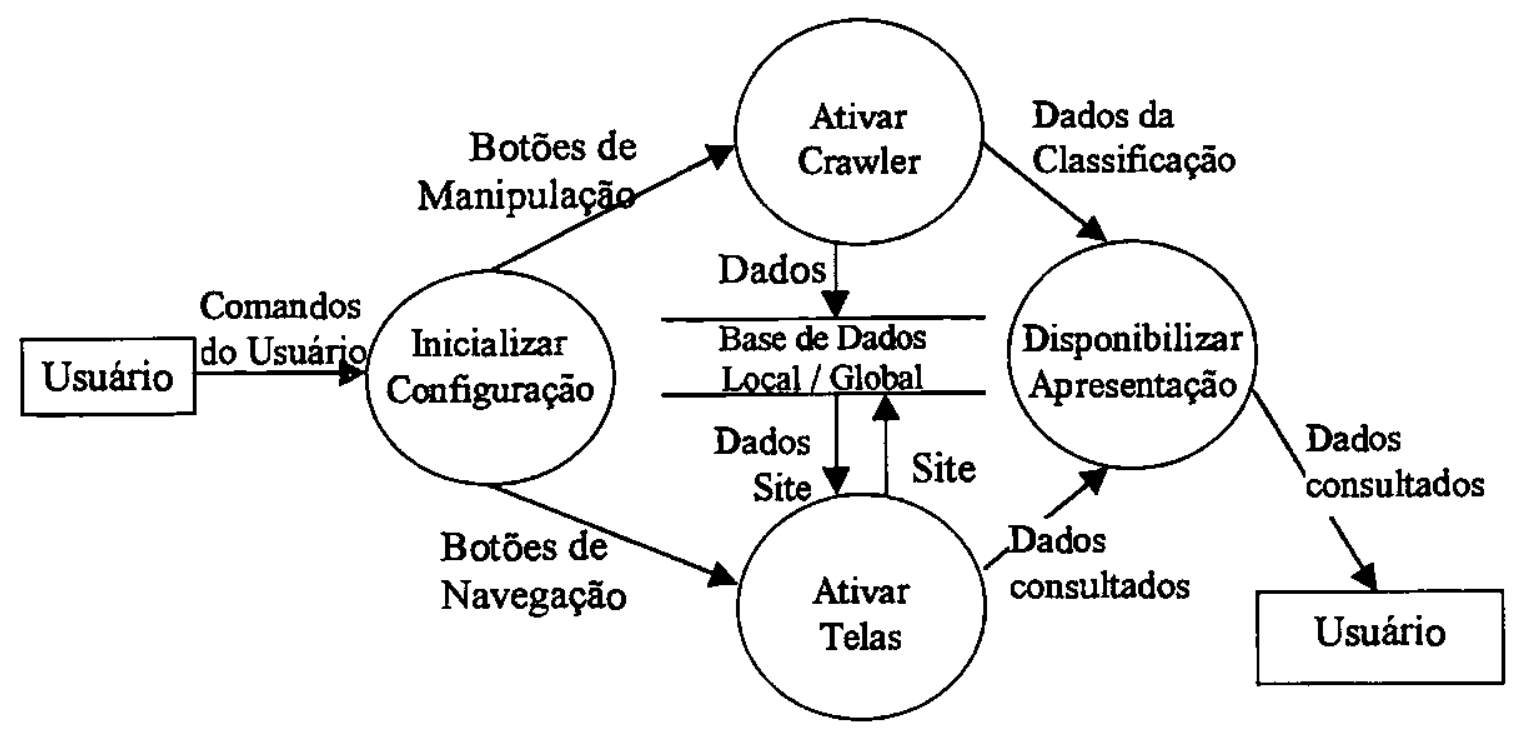

Figura 16. DFD nivel 1 da Ferramenta DB-LiOS ${ }^{E}$

As funçōes apresentadas no DFD de nivel 1 (Figura 16) da ferramenta, são descritas a seguir:

- Inicializar Configuração: verifica se as configurações no OBDC e no BDE estão corretas, caso não existam as configurações necessárias, o procedimento instala os componientes necessários. Esse processo também verifica se existe um identificador para o usuário, caso não exista o cadastro é feito para que o usuário fique cadastrado na base global. Após as instalaçöes estarem corretas, a tela principal da ferramenta é ativada (vide Figura 9) a espera de um comando do usuário.

- Ativar Crawler: o crawler conta com as funcionalidades: extração de links das páginas; classificaçāo dos links; e apresentação dos indicativos de qualidade ao autor. Essas funçōes foram descritas na Seção 5.2 e complementadas na Seção 5.3.

- Ativar Telas: este processo ativa a função solicitada pelo usuário, que pode selecionar uma das funçōes: Botão Incluir, Botão Excluir, Botão Reload, Botão Refresh, Selecionar uma das Classificações de Links e verificar as análises feitas (Botão Caso 0 até Botão Caso 7), Selecionar todos os Links existentes (Botão Todos), Verificar os Links que levam a Páginas Mortas (Pesquisa), Botão Gráfico, Botão Estatística, Botão Página (Mortas, Boas, Não Encontradas, Timeout e Desconhecidas), Botão Primeiro, Anterior, Próximo e Último, ou algumas funções que constam no Menu da ferramenta, Configurações de Usuário e Sistema, Opção de Navegação, Transferência a Base Global e Conexão à Base Global. O Quadro 5 mostra de forma resumida as funções disponiveis na tela principal com suas devidas descriçס̋es. 
Quadro 5. Descrições das Funções Disponíveis ao Usuário

\begin{tabular}{|c|c|}
\hline Função & Descrição \\
\hline $\begin{array}{l}\text { Conexão à Base } \\
\text { Global (Menu) }\end{array}$ & $\begin{array}{l}\text { Permite navegar na base compartilhada por todos os usuários da } \\
\text { ferramenta e não mais na sua própria base de dados. }\end{array}$ \\
\hline $\begin{array}{c}\text { Transferência à } \\
\text { Base Global (Menu) }\end{array}$ & Transfere os dados armazenados na base local à base global. \\
\hline $\begin{array}{l}\text { Configuraçōes de } \\
\text { Usuário (Menu) }\end{array}$ & $\begin{array}{l}\text { Permite alterar os dados do usuário (nome, endereço, cidade, uf, } \\
\text { cep, país, e-mail, profissão). Esses dados são cadastrados na } \\
\text { instalaçäo da ferramenta. }\end{array}$ \\
\hline $\begin{array}{l}\text { Configurações de } \\
\text { Sistema (Menu) }\end{array}$ & $\begin{array}{l}\text { Permite alterar dois campos, TimeOut e Reload (TimeOut). O } \\
\text { campo TimeOut serve para configurar o tempo de espera para } \\
\text { leitura da página. Esse tempo de leitura quem controla é o } \\
\text { crawler e caso esse tempo estipulado seja ultrapassado, a } \\
\text { página fica com status de timeout. É possivel também que o } \\
\text { crawler faça outras tentativas de leitura da página antes de } \\
\text { colocar o status de timeout, dessa maneira, o campo Reload } \\
\text { (TimeOut) deve ser setado para o número de tentativas que você } \\
\text { deseja que o crawler faça antes de colocar o status de timeout. } \\
\text { Se estes campos não forem configurados, o padrão para } \\
\text { TimeOut é } 60 \text { segundos e o número de tentativas - Reload } \\
\text { (TimeOut)-é de } 10 \text { vezes. }\end{array}$ \\
\hline $\begin{array}{c}\text { Opção de } \\
\text { Navegação (Menu) }\end{array}$ & $\begin{array}{l}\text { Como existe um controle de versão para os sites, esta opção } \\
\text { permite com que a navegação seja feita nas diversas versōes } \\
\text { existentes de um site, ou permite navegar entre todos os sites } \\
\text { existentes. }\end{array}$ \\
\hline Ajuda (Menu) & Apresenta um help para utilizaçāo da ferramenta. \\
\hline Sair (Menu) & Utilizado para sair do programa. \\
\hline Botão Primeiro & $\begin{array}{l}\text { Utilizado para navegar na base de dados existente, esta } \\
\text { navegação entre os registros pode ser nos sites ou nas versōes } \\
\text { dos sites, dependendo da escolha feita em Opção de } \\
\text { Navegação. O botão Primeiro se referencia ao primeiro registro } \\
\text { do arquivo. }\end{array}$ \\
\hline Botão Anterior & $\begin{array}{l}\text { Utilizado para navegar na base de dados existente, esta } \\
\text { navegação entre os registros pode ser nos sites ou nas versōes } \\
\text { dos sites, dependendo da escólha feita em Opção de } \\
\text { Navegação. O botăo Anterior mostra o registro anterior ao que } \\
\text { está sendo exibido em teia. }\end{array}$ \\
\hline Botão Próximo & $\begin{array}{l}\text { Utilizado para navegar na base de dados existente, esta } \\
\text { navegaçăo entre os registros pode ser nos sites ou nas versões } \\
\text { dos sites, dependendo da escolha feita em Opção de } \\
\text { Navegação. O botäo Próximo mostra o próximo registro ao que } \\
\text { está sendo mostrado em tela }\end{array}$ \\
\hline Botão Último & $\begin{array}{l}\text { Utilizado para navegar na base de dados existente, esta } \\
\text { navegação entre os registros pode ser nos sites ou nas versões } \\
\text { dos sites, dependendo da escolha feita em Opção de } \\
\text { Navegaçáo. O botão Último exibe o último registro do arquivo. }\end{array}$ \\
\hline Botão Incluir & $\begin{array}{l}\text { Submete um site a avaliação. Deve-se informar o endereço do } \\
\text { site a ser avaliado e o botão Start deve ser ativado de modo que } \\
\text { o processo de classificação de links seja iniciado. Ressalta-se } \\
\text { aqui que caso já exista uma avaliação desse site na base de } \\
\text { dados da ferramenta, automaticamente é criada uma nova } \\
\text { versão para esse site. A versão é exibida na tela principal em } \\
\text { formato de data e hora. }\end{array}$ \\
\hline Botão Excluir & $\begin{array}{l}\text { Como o próprio nome sugere, serve para exclusão do site - } \\
\text { apaga todas as versões disponíveis do site - ou da versão de um } \\
\text { site. }\end{array}$ \\
\hline
\end{tabular}




\begin{tabular}{|c|c|}
\hline Botão Reload & $\begin{array}{l}\text { Faz uma nova leitura do site em questão, somente atualizando } \\
\text { os dados. }\end{array}$ \\
\hline Botão Refresh & $\begin{array}{l}\text { Faz com que as páginas que não foram lidas - por problemas } \\
\text { desconhecidos ou simplesmente por que o usuánio interrompeu } \\
\text { a classificação - sejam lidas e então a atualização dos dados é } \\
\text { feita. }\end{array}$ \\
\hline Botão Estatística & $\begin{array}{l}\text { Acessa todas as informações referentes ao site analisado de } \\
\text { forma resumida. Nessa tela é possivel verificar quantas páginas } \\
\text { existem no site, quantas são boas e quantas são mortas. É } \\
\text { possivel notar o total de links existentes, năo lidos, timeout, } \\
\text { quantos links são desconhecidos, assim como os links que estão } \\
\text { bons e que estäo mortos. São observáveis também todos os } \\
\text { casos de links com sua correspondente porcentagem. }\end{array}$ \\
\hline Botão Gráfico & de links propostos. \\
\hline Botão & $\begin{array}{l}\text { Exibe todas as páginas existentes no site, páginas não } \\
\text { encontradas (o processo de classificaçäo foi interrompido), as } \\
\text { que apresentaram o status de timeout (o tempo de espera do } \\
\text { crawler foi ultrapassado), as desconhecidas (o HTTP retoma um } \\
\text { código de erro diferente de 200), as mortas (as páginas que não } \\
\text { existem no site) ou as páginas boas. }\end{array}$ \\
\hline Botấ & $\begin{array}{l}\text { os links pertencentes ao caso de Dependência de } \\
\text { Ia análise. }\end{array}$ \\
\hline Boté & $\begin{array}{l}\text { Exibe todos os links pertencentes ao caso denominado } \\
\text { Informaçסes Específicas e sua análise. }\end{array}$ \\
\hline Bot & $\begin{array}{l}\text { Exibe todos os links pertencentes ao caso denominado } \\
\text { Padronização de Links e sua análise. }\end{array}$ \\
\hline Bot & $\begin{array}{l}\text { os links pertencentes ao caso denominado Reforço } \\
\text { ua análise. }\end{array}$ \\
\hline Bot: & $\begin{array}{l}\text { Exibe todos os links pertencentes ao caso denominado indices } \\
\text { e sua análise. }\end{array}$ \\
\hline Botäc & $\begin{array}{l}\text { Exibe todos os links pertencentes ao caso denominado } \\
\text { Redundância de Informaçöes e sua análise. }\end{array}$ \\
\hline Botã & $\begin{array}{l}\text { os links pertencentes ao caso denominado Palavras } \\
\text { as e sua análise. }\end{array}$ \\
\hline $\bar{B}$ & $\begin{array}{l}\text { Exibe todos os links pertencentes ao caso denominado ícones e } \\
\text { sua análise. }\end{array}$ \\
\hline E & $\begin{array}{l}\text { Exibe todos os links do referido site sem distinção dos casos de } \\
\text { links propostos. }\end{array}$ \\
\hline Botão Pesquisa & ibe os links q \\
\hline
\end{tabular}

- Disponibilizar Apresentação: permite a visualização dos dados solicitados pelo usuário e ao finalizar a tarefa retoma a tela principal (vide Figura 9).

\subsection{Estudos de Casos}

$O$ estudo de caso realizado para testes iniciais e informais sobre a ferramenta e sua validação contou com a leitura de 32 sites educacionais, ou seja, são sites disponiveis na WWW e que têm como objetivo "ensinar algo" aos alunos e outros 41 sites que não tinham como objetivo ensinar algo, ou seja, eram sites não educacionais. Nos sites educacionais, os casos avaliados eram disciplinas oferecidas em universidades ou cursos oferecidos na $\mathrm{mWW}$, tais como: 
fotografia, história e música. Os sites avaliados foram tanto de âmbito nacional como internacional.

O estudo de caso em sites independente de domínio foi feito, pois durante esta pesquisa foi possivel observar que outros criténios de qualidade propostos para qualquer domínio poderiam ser usados na proposta de caso de reuso de links (Fortes, 1996), (Fortes et al., 1997), (Fortes \& Nicoletti, 1999). Dessa forma um estudo de caso foi feito para verificar se a ferramenta desenvolvida para atingir critérios educacionais, poderia também ser utilizada independente de domínio.

\subsubsection{Estudos de Casos no Domínio Educacional}

$\mathrm{Na}$ Tabela 1 são apresentados de forma resumida os 32 sites avaliados e a quantidade de links encontrados em cada caso. Com os estudos realizados foram lidos 9756 links e 1825 páginas. Ressaltando que um link pode pertencer a mais de um caso de link.

Tabela 1. Resultados dos Casos por Site

\begin{tabular}{|c|c|c|c|c|c|c|c|c|}
\hline \multirow{2}{*}{ Site } & \multicolumn{8}{|c|}{ Casos de Links } \\
\hline & $\mathbf{0}$ & 1 & 2 & 3 & 4 & 5 & 6 & 7 \\
\hline www.lcmc.sc.usp.br/ mdgvnune/sce126/ & 13 & 34 & 4 & 7 & 95 & 4 & 0 & 0 \\
\hline www.intermidia.icmc.sc.usp.br/ mmpg/ & 2 & 5 & 36 & 74 & 90 & 0 & 42 & 0 \\
\hline $\begin{array}{l}\text { chapinha.intermidia.icmsc.sc.usp.br/rede } \\
\text { s/ }\end{array}$ & 2 & 62 & 43 & 86 & 198 & 2 & 28 & 5 \\
\hline $\begin{array}{l}\text { www.icmc.sc.usp.br/ mdgvnune/downlo } \\
\text { ad/sce5832/Teoria.html/ }\end{array}$ & 58 & 14 & 25 & 61 & 129 & 2 & 12 & 0 \\
\hline www.icmc.sc.usp.br/manuals/HTML & 0 & 38 & 11 & 569 & 614 & 51 & 13 & 400 \\
\hline $\begin{array}{l}\text { www.icmc.sc.usp.br/ mdgvnune/LP/inde } \\
\text { x.html/ }\end{array}$ & 0 & 414 & 356 & 250 & 648 & 83 & 32 & 0 \\
\hline www.icmc.sc.usp.br/ Ecursos/sce183/ & 2 & 121 & 59 & 111 & 275 & 4 & 0 & 7 \\
\hline tapioca.icmc.sc.usp.br/\%7Ecursos/sce18 & 0 & 150 & 58 & 204 & 351 & 21 & 80 & 8 \\
\hline $\begin{array}{l}\text { tapioca.icmc.sc.usp.br/ mdgvnune/\%7E } \\
\text { cursos/sce201/ }\end{array}$ & 0 & 3 & 1 & 32 & 42 & 2 & 4 & 50 \\
\hline $\begin{array}{l}\text { www.euronet.nl/users/menke/songs.html } \\
\text { \#menu }\end{array}$ & 0 & 29 & 9 & 209 & 330 & 223 & 19 & 147 \\
\hline $\begin{array}{l}\text { www.webproforum.com/opt_net/index.ht } \\
\mathrm{ml}\end{array}$ & 0 & 0 & 39 & 587 & 428 & 176 & 63 & 46 \\
\hline $\begin{array}{l}\text { www.insoft.softex.br/ projead/curso/inde } \\
\text { x.html }\end{array}$ & 1 & 12 & 0 & 0 & 21 & 0 & 0 & 6 \\
\hline $\begin{array}{l}\text { trochim.human.cornell.edu/webeval/web } \\
\text { eval.htm }\end{array}$ & 1 & 15 & 2 & 47 & 113 & 12 & 0 & 4 \\
\hline $\begin{array}{l}\text { quest.arc.nasa.gov/lessons- } \\
\text { leamed/lessons-leamed-index.html }\end{array}$ & 0 & 7 & 0 & 6 & 34 & 4 & 0 & 0 \\
\hline www.din.uem.br/ acarniel/homepgv.html & 1 & 1 & 0 & 8 & 18 & 2 & 2 & 0 \\
\hline $\begin{array}{l}\text { www.ibilce.unesp.br/courseware/winnt/d } \\
\text { efault.htm }\end{array}$ & 0 & 18 & 3 & 38 & 92 & 22 & 0 & 91 \\
\hline $\begin{array}{l}\text { www.jbilce.unesp.br/courseware/ppt200 } \\
\text { O/contents.htm }\end{array}$ & 0 & 7 & 0 & 44 & 57 & 4 & 0 & 16 \\
\hline
\end{tabular}




\begin{tabular}{|l|c|c|c|c|c|c|c|c|}
\hline $\begin{array}{l}\text { www.ibilce.unesp.br/courseware/wor } \\
\text { d2000/default.htm }\end{array}$ & 0 & 10 & 0 & 0 & 28 & 0 & 0 & 0 \\
\hline $\begin{array}{l}\text { www.ibilce.unesp.br/courseware/exc } \\
\text { el/default.htm }\end{array}$ & 0 & 21 & 0 & 38 & 41 & 23 & 2 & 326 \\
\hline $\begin{array}{l}\text { www.ibilce.unesp.br/courseware/wor } \\
\text { d/default.htm }\end{array}$ & 0 & 47 & 24 & 15 & 57 & 26 & 4 & 162 \\
\hline $\begin{array}{l}\text { www.prudente.unesp.br/dcartog/ar/ete/h } \\
\text { p_arlete/courseware/intgeo.htm }\end{array}$ & 0 & 49 & 79 & 77 & 232 & 13 & 13 & 7 \\
\hline ww.dartmouth.edu/ cc/about/intro.htm/ & 0 & 0 & 0 & 19 & 52 & 0 & 0 & 0 \\
\hline www.icmsc.sc.usp.br/manuals/ssce763/ & 0 & 10 & 0 & 40 & 49 & 3 & 0 & 0 \\
\hline $\begin{array}{l}\text { penta.ufrgs.br/Esmilda/hello/estruc- } \\
\text { dados.html }\end{array}$ & 0 & 0 & 0 & 0 & 3 & 0 & 0 & 0 \\
\hline $\begin{array}{l}\text { www.dca.fee.unicamp.br/courses/Poola } \\
\text { va/1998/UseOO/index.html }\end{array}$ & 0 & 0 & 0 & 6 & 9 & 0 & 0 & 0 \\
\hline www.cisc.sc.usp.br/tutoriais/msword/ & 0 & 105 & 0 & 40 & 149 & 90 & 0 & 0 \\
\hline $\begin{array}{l}\text { www.fortunecity.com/skyscraper/teln } \\
\text { et/393/tutorial/index.html }\end{array}$ & 0 & 0 & 0 & 0 & 18 & 0 & 0 & 0 \\
\hline www.scism.sbu.ac.uk/law/ & 0 & 646 & 39 & 103 & 939 & 27 & 0 & 12 \\
\hline www.Inf.ufsc.br/ renata/poo.htm & 0 & 5 & 0 & 5 & 26 & 0 & 0 & 0 \\
\hline www.geocities.com/Eureka/Park/4141/ & 0 & 252 & 218 & 183 & 417 & 8 & 17 & 0 \\
\hline www.ufsc.br/scra/jussara/index.html & 0 & 69 & 37 & 15 & 96 & 2 & 0 & 0 \\
\hline $\begin{array}{l}\text { www.library.wisc.edu/etext//Reader/Th } \\
\text { waites/Contents.html }\end{array}$ & 0 & 375 & 351 & 851 & 1058 & 59 & 452 & 0 \\
\hline TOTAL... & 80 & 2519 & 1394 & 3725 & 6709 & 863 & 783 & 1287 \\
\hline
\end{tabular}

A partir desse estudo foram feitas duas análises: a primeira análise foi feita com base no caso que teve maior incidência em cada site, foi observado qual o caso que mais ocorre e, na segunda análise foram somadas todas as quantidades de links ocorridos em cada caso e verificou-se qual o caso que tinha a maior quantidade no total.

Com a primeira análise feita foi possivel observar que a maioria dos casos encontrados tratavase do caso de Indices (Caso 4), ou seja, era visível que o hiperdocumento foi feito da mesma forma que a nossa leitura/redação habitual, àquela encontrada nos livros e materiais impressos. O segundo caso mais freqüente é o caso 7 , ou seja, a utilização de ĺcones. $E$, na seqüéncia, o caso 3 (Reforço ao Aluno) aparece em terceiro lugar. Assim, as incidéncias dos

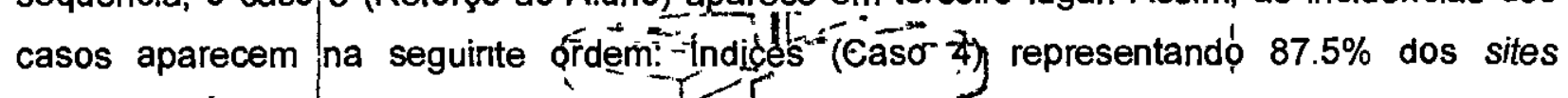
estudados, ĺcones (Caso 7) representânó $9.37 \%$ e-Reforço ao Aluno (Caso 3) representando $3.13 \%$. Entre os demais casos, nenhum deles teve uma quantidade representativa de links no site, e dessa forma nessa análise só foram levados em consideração os 3 casos citados: Índice, ĺcones e Reforço ao Aluno.

Dessa forma obteve-se 28 estudos que tiveram uma incidência maior no caso Índice, sendo que dentro das ocorrências de Indice os casos que mais ocorreram foram Reforço ao Aluno (13 sites), Informações Específicas (9 sites), ícones (2 sites) e Padronização de Links e Redundância de Informaçס̋es (1 site) e 2 sites que se mostraram anômalos, que nestes 2 sites 
só ocorreu o caso 4 (Índices), apesar de ter uma incidência de caso diferente dos demais casos, isto aconteceu pois o site conta com um índices em todas as páginas como se fosse um frame.

Dos outros 3 estudos, em 2 sites o caso mais freqüente foi Ícone seguido por Índice, sendo que depois, 2 sites pertencem ao caso Reforço ao Aluno e 1 site pertence à Padronização de Links. Por último, em um dos sites analisados, obteve-se o caso 3 (Reforço ao Aluno) como o mais freqüente, seguido por Índices (Caso 4). Com esses resultados foi possivel observar que mesmo que ocorram outros casos, a incidência do Caso 4 (Índices) e do Caso 3 (Reforço ao Aluno) é bastante comum.

$\mathrm{Na}$ segunda análise foi feita a somatória total dos links em cada caso, na Tabela 1 se refere à linha de Total. O gráfico resultante desta análise é mostrado na Figura 17. E através dela é possível verificar que o caso que mais ocorre é Índices (39\%), seguido pelo Reforço ao Aluno (21\%), Informações Específicas (15\%), Padronização de Links (8\%), Ícones (7\%), na seqüência aparecem Redundância de Informações e Palavras Significativas com $5 \%$ e o último caso é a Dependência de Browser praticamente com $0 \%$ em função dos outros casos.

Pode-se notar que na primeira análise feita o caso Reforço ao Aluno aparece na terceira posição e ao somarmos a incidência total dos links em cada caso (segunda análise), o caso Reforço ao Aluno representa $21 \%$, ocupando a Segunda posição dos casos que mais ocorrem. Isso acontece por que na primeira análise mesmo que os casos que têm maior incidência seja Índice ou Ícone, na seqüência o que mais ocorre é o caso de Reforço ao Aluno, e dessa forma o total reflete essa ocorrência.

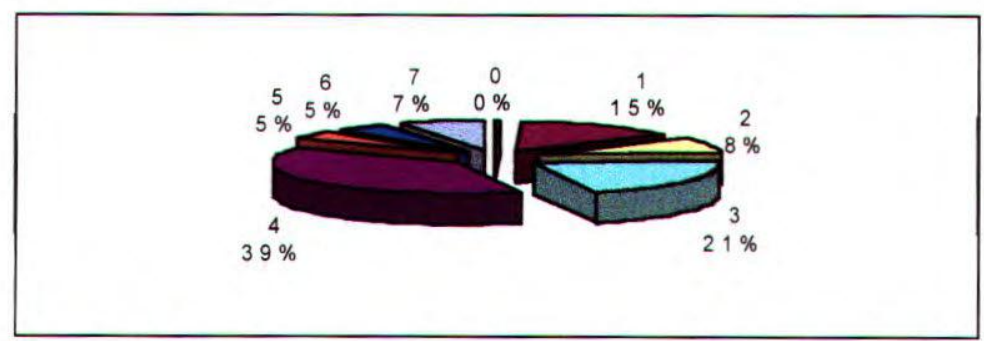

Figura 17. Gráfico dos Percentuais dos Casos Encontrados

Com essas análises algumas observações foram feitas: referente aos nomes significativos dados aos casos de links, foi possível verificar que os nomes significativos atribuídos aos casos de links condizem com os dados apresentados e que, na sua maioria, o uso de índices é o mais utilizado. Alguns motivos para se utilizar os Índices são: facilitar ao usuário uma pesquisa 
a um tópico específico, diminuindo o caminho a ser percorrido até encontrar uma informação e dessa forma, diminuir a sobrecarga cognitiva exigida; e pela semelhança com a leitura em papel, a qual o usuário já está habituado. O Reforço ao Aluno também tem uma porcentagem significativa no geral, e isso é muito proveitoso ao usuário, pois pode facilitar seu aprendizado. E o caso 0 (Dependência de Browser) è o que menos ocorre, o que também justifica, pois, atualmente os recursos para facilitar a navegação do usuário são bastante explorados.

Apesar do caso Dependência de Browser não possuir um número significativo de ocorrência, na análise dos sites foram encontradas páginas que não contavam com nenhum link. Dessa forma essa página não entrava em nenhuma classificação de links, mas era essencial que esse número fosse computado, pois esses números expressam uma forma de dependência de browser, o que pode significar falta de qualidade. Dessa maneira, computou-se esse número no que foi denominado Pagina 0 , que nada mais é que uma página com nenhum caso de links. Com isso verificou-se que apesar da Dependência de Browser (Caso 0) ter pouca ocorrência (quase $0 \%$ em relação ao total), ainda existe um grande número de páginas a ser reformulada, pois a incidência da classificação da Página 0 foi de $18 \%$, ou seja, aproximadamente 337 páginas das 1825 páginas avaliadas não contam com nenhum tipo de link.

\subsubsection{Estudos de Casos Independentes de Domínio}

Com o objetivo de venificar a existência de alguma semelhança ou diferença entre os casos encontrados nos sites educacionais ou encontrados em sites de outros dominios, avaliou-se outros sites fora do domínio educacional, e pode-se observar que mesmo sendo de outro dominio, o caso mais freqüente ainda é o de índices (Caso 4), isso se deve às vantagens na utilização deste caso (vide Seção 5.4.1). Na sequiência, diferenciando do domínio educacional onde a segunda maior incidência ocorre nos ícones (Caso 7), em domínio não educacional o caso que mais ocorre é o Caso 3, isso demonstra que a denominação colocada ao caso 3 só é cabivel a softwares educacionais e para um domínio geral este caso deveria levar nova titulação de forma que representasse semanticamente a forma de retorno à página principal. Ainda considerando a freqüência ocorrida em cada site, a incidência do caso Informações Especificas (Caso 1) è o caso que vina na seqüência, seguido pelos demais casos em esçalas menores.

Nestes estudos realizados foram lidos 239.255 links e 21.880 páginas. Ressaltando, novamente, que um link pode pertencer a mais de um caso de link. Assim como aconteceu no domínio educacional, não houve grande incidência do caso 0 (Dependência de Browser), mas 
aproximadamente $23 \%$ das páginas não contavam com nenhum tipo de link, ou seja, havia uma dependência de browser e por este motivo às páginas deveriam ser revistas.

Conclui-se então que em sites de outros dominios (não educacionais) a preocupação é que o hiperdocumento seja de fácil compreensão e que as informações sejam buscadas de forma rápida e retornem a um ponto comum. Dessa forma a presença dos casos 4 (índices), 3 (Reforço ao Aluno) e 1 (Informações Específicas) representam, respectivamente, uma forma de indices para auxiliar a procura de informações e os casos 3 e 1 representam um retorno a um lugar comum para que o usuánio não se perca na navegação. A última conclusão seria que a ferramenta deveria sofrer uma alteração para que sites independentes de dominio fossem atendidos, pois neste trabalho a preocupação foi feita com base no domínio educacional $e_{\text {, }}$ portanto, as avaliações sugeridas ao usuário nem sempre são condizentes com a nova realidade.

\subsection{Considerações Finais}

Com os estudos de casos feitos, observou-se outros aspectos interessantes que também devem ser ressaltados. Os casos denominados Dependência de Browser (Caso 0), Informaçōes Especificas (Caso 1), Padronização de Links (Caso 2) e Reforço ao Aluno (Caso 3) representam uma leitura seqüencial ao hiperdocumento, pois se nesses casos ocorrer mais algum link, eles passam a pertencer aos outros casos $(4,5,6$ e 7) e daí existe a leitura não seqüencial, ou seja, o usuário tem mais de uma opção de escolha para navegar.

Outro aspecto visto foi a grande ocorrência de índices nos sites, isso indica que o usuário conta com a existência dos Indices, fazendo com os tópicos que o aluno deseja estudar seja mais fácil de ser localizado.

Com a ferramenta foi possivel também verificar, através da classificação das páginas, que muitas páginas não possuíam links, que não deve ser confundido com o caso denominado Dependência de Browser (Caso 0), pois nesse caso há ao menos um link. Mas a classificação de Página $O$ é uma forma de Dependência de Browser e quando houver uma grande incidência deste caso, o site deve ser revisto para que seja melhorado de forma a facilitar a navegação pelo usuário.

De fato a ferramenta, como forma automática de avaliar um site de hipermídia educacional, não deve substituir os mecanismos para avaliação de atributos propostos na literatura. No entanto, acredita-se que se uma aplicação hipermidia educacional for submetida à análise estrutural 
proposta, existirāo mais chances de melhorias no hiperdocumento devido à facilidade de observação dos requisitos de qualidade esperados. Portanto, a abordagem aqui proposta consiste em uma forma de auxilio ao autor para que ao menos alguns requisitos de qualidade sejam observados. Além disso, a aplicação hipermídia educacional precisa mais do que uma análise estrutural, necessitando sempre de uma análise do conteúdo das informaçöes disponíveis, cujos especialistas da área pedagógica têm plena competência, autoridade e responsabilidade sobre o mesmo.

Finalizando, a idéia de se utilizar à ferramenta independente de domínio deve contar com um estudo mais aprofundado para que os casos tenham uma denominação mais coerente, as denominaçöes propostas, realmente, só atendem o domínio educacional. 
Com a disseminação da Internet e com a grande quantidade de hiperdocumentos disponiveis nos sites, fica claro que esses hiperdocumentos devem possuir qualidade. Mas devido a construção de um hiperdocumento envolver milhares de páginas e links, o trabalho manual na avaliação desses hiperdocumentos se torna trabalhoso. Com isso em mente, o objetivo deste trabalho foi auxiliar a avaliação estrutural de hipermídia educacional através de técnicas da Engenharia de Software.

Dessa forma, para a pesquisa desenvolvida neste trabalho foram verificadas as caracteristicas que devem constar nas aplicações hipermídia educacionais, assim como as vantagens e desvantagens de sua utilização. Apesar da aplicação hipermídia educacional apresentar problemas, deve-se sempre buscar soluções para esses problemas, em função do potencial tecnológico que deve ser aproveitado em beneficio da evolução dos paradigmas educacionais. Enfim, a hipermídia deve ser desenvolvida de maneira coerente para que possa trazer benefícios para a área pedagógica.

Um aspecto importante observado foi que na criação de uma aplicação hipermídia educacional deve-se contar com a colaboração de professores, programadores, alunos e um bom projeto. Se a aplicação hipermídia atender a todas ou a maioria das especificações feitas, ela terá mais chance de possuir qualidade. Recentemente, qualidade é um requisito básico em qualquer produto ou serviço.

Apesar de ser um requisito básico, não é fácil obter qualidade nos produtos e serviços, uma vez que qualidade é uma medida indireta $\theta$ depende do ponto de vista da pessoa que está julgando o produto. $O$ termo qualidade em hipermídia ainda não possui uma definição consolidada. Dessa maneira, os esforços feitos para obtenção de qualquer indício de qualidade são através de métodos, abordagens e métricas propostas.

Neste trabalho os esforços foram concentrados na busca por qualidade em hipermídia educacional, de maneira que indicativos de qualidade propostos sejam mais eficazes. Por não se possulr qualificações para avaliar o âmbito pedagógico desenvolvido nas aplicações, somente o lado computacional foi questionado e dentro dos aspectos computacionais, preocupou-se com a análise estrutural do hiperdocumento. 
Neste contexto, foram definidos neste trabalho alguns atributos relevantes para a avaliação de qualidade em aplicações hipermídia educacionais. Ressaltou-se a importância de qualidade na utilização de um hipermídia educacional e também a necessidade dos hiperdocumentos disponiveis estarem sempre acompanhados de qualidade.

É importante salientar que a proposta descrita foi implementada na forma de uma ferramenta, DB-LiOS ${ }^{E}$, para que os atributos fossem obtidos de forma automática, simplificando assim a sua utilização por parte dos autores. Com a ferramenta é possível analisar um site, verificando os indicativos obtidos e suas descriçōes, para que o hipermídia entre em um processo de melhoria contínua.

Muito embora se saiba de outros fatores inerentes à avaliação estrutural que devem ser analisados, foi importante a investigação e os estudos realizados para que se pudesse ter um conjunto real de possibilidades a serem avaliadas em hipermídia educacionais.

Além da usabilidade que foi tratada neste trabalho, considera-se de extrema importância à análise do conteúdo educacional. Salienta-se novamente que para a análise desse conteúdo seria imprescindível à colaboração de profissionais da área pedagógica, o que não ocorreu. Uma sugestão seria desenvolver um questionário em conjunto com as pessoas responsáveis, especialistas da área pedagógica e implementar essa nova proposta na ferramenta DB-LiOS ${ }^{\mathrm{E}}$. Dessa forma, a ferramenta se tornaria mais completa por tratar os dois lados envolvidos: o lado pedagógico e o lado computacional.

Verificou-se também que apesar de existirem trabalhos focalizando a qualidade de aplicação de software, existe muito por ser feito. Muitos sites analisados (e não somente os de domínio educacional) contam com páginas ou links inexistentes apesar dos esforços feitos nas ferramentas de autoria para solucionar esse problema.

Apesar de não ter sido feita uma pesquisa com os autores dos sites analisados, pode-se perceber que as aplicaçōes hipermídia são construídas e alteradas sem controle e, portanto, a manutenção possui um problema de ordem cultural. Os desenvolvedores de software precisam ter consciência da importância do controle de qualidade. Como atualmente a exigência pela qualidade é alta e os profissionais da área estão tentando se adaptar a alguns controles de qualidade, poderia ser feito um plano de ação para se conseguir qualidade nos desenvolvimentos das aplicações hipermídia educacionais. 
Outra idéia de melhoria para a ferramenta seria avaliar também códigos XML (eXtensible Mark Up Language). Atualmente da maneira que a ferramenta foi implementada seria necessário um parser para transformar o código XML em HTML, para depois submetê-lo a avaliação.

A partir dos estudos feitos em aplicações hipermídia independentes de domínio, observou-se que as propostas de semânticas para os casos de links não sāo cabíveis e, portanto, outro trabalho futuro seria uma adaptação desses critérios para que, independentente de domínio, a ferramenta fornecesse uma análise do que deveria ser feito. A ferramenta DB-LiOS (Seraphim, 2000) tem o objetivo de avaliar os sites independente de domínio, mas não fornece indicativos de qualidade ao autor, sendo necessário o conhecimento dos casos para que alguma providência seja tomada.

Apesar dos esforços realizados, muito ainda deve ser feito para melhorar a qualidade de software de maneira geral. Este trabalho apresenta uma contribuição para se obter uma melhoria de qualidade na parte estrutural de uma aplicação hipermídia educacional. Sabe-se da dificuldade que um professor tem ao desenvolver um site e por esse motivo a ferramenta se mostra amigável para ajudá-lo a obter mais critérios de qualidade na sua aplicação. 
(Akhras \& Self, 1995) AKHRAS, F. N.; SELF, J. A. Process-oriented Perspective on Analysing Leaner-environments in Construtivism Learning. In: Simpósio Brasileiro de Informática na Educação, 6., Florianópolis - SC - Brasil, 1995. Anais.

(Amante, 1994) AMANTE, L. Uma aplicação em Hipertexto/Multimídia: O Desenho Infantil. In: Comunicaçōes do II Congresso Ibero-americano de Informática na Educaçāo, Lisboa - Portugal, 1994. Anais. p.315-322.

(Bernstein, 1998) BERNSTEIN, Mark. Patterns of Hypertext. In: HyperText'98. Pittsburgh PA USA, 1999. Proceedings. p. 21-29.

(Blumenschein \& Freitas, 2000) BLUMENSCHEIN A. \& FREITAS, L. C. T. Manual Simplificado de Comércio Eletrônico. Editora Aquariana, São Paulo, 2000.

(Botafogo et al., 1992) BOTAFOGO, Rodrigo A.; RIVLIN, Ehud; SHNEIDERMAN, Bem.

Structural Analysis of Hypertexts: Identifying Hierarchies and Useful Metrics.

ACM Transactions on Information Systems, v.10, n.2, p.142-180, abril 1992.

(Brown, 1990) BROWN, P. J. Assessing the Quality of Hypertext Documents. In: European Conference on Hypertext, Versailes, França, novembro 1990. Proceedings. p.112.

(Campos, 1994) CAMPOS, F. C. A. Hipermídia na Educação: Paradigmas e Avaliação da Qualidade. 1994. 139p. Dissertação (Mestrado) - COPPE - UFRJ.

(Campos, 1994b) CAMPOS, G. H. B. Metodologia para avaliação da qualidade de software educacional. Diretrizes para desenvolvedores e usuários. 1994. 234p. Dissertação (Doutorado) - COPPE - UFRJ.

(Campos \& Campos, 1997) CAMPOS, F. C. A.; CAMPOS, H. B. Design Instrucional, Novas Tecnologias e Desenvolvimento de Software Educacional. In: Simpósio Brasileiro de Informática na Educação, 8., São José dos Campos - SP - Brasil, 1997. Anais. p. 289-311.

(Campos et al., 1999) CAMPOS, F. C. A.; CAMPOS, G. H. B.; ROCHA, A. R. C. Tradicionalismo $X$ Inovação: A Informática Educativa nas Escolas Brasileiras. In: Workshop de Informática na Escola, 5., Rio de Janeiro - RJ - Brasil, 1999. Anais. p. 613-625.

(Carraher, 1990) CARRAHER, D. W. O que esperamos do software educacional. Acesso FDE - Revista de Educação e Informática, 2(3), 32-36, jan/jun 1990. 
(Cho et al., 1998) CHO, J.; GARCIA-MOLINA, H.; PAGE, L.; Efficient crawling throaugh URL ordering. In: International WWW Conference, $7^{\text {th }}$, Brisbane - Australia. April de 1998. Proceedings.

(Conklin, 1987) CONKLIN, J. Hypertext: An Introduction and Survey. Computer, v.20, n.9, p.1741, seternbro 1987.

(Fenton, 1991) FENTON, N. Software Metrics. New York, Chapman \& Hall, 1991.

(Fenton \& Pfleeger, 1997) FENTON, Norman E.; PFLEEGER, Shari L. Software Metrics - A Rigorous \& Practical Approach. $2^{\text {nd }}$ Edition, Boston, Thompson Computer Press, 1997.

(Fielding et al., 1999) FIELDING, R. et al. Hypertext Transfer Protocol - HTTP/1.1. Intemet Official Protocol Standards RFC-2616, junho de 1999, visitado em outubro 1999, http://www.rfc-editor.org/rfc/rfc2616.txt.

(Fortes, 1996) FORTES, R. P. M. Análise e Avaliação de Hiperdocumentos: uma abordagem baseada na Representação Estrutural. Sāo Carlos, 1996. 179p. Tese (Doutorado) - IFSC, USP.

(Fortes et al. 1997) FORTES, R.P.M.; NICOLETTI, M.C.; GARCIA NETO, A. A Formal Approach to Consistency and Reuse of Links in World-Wide Web Applications. In: PALANQUE, P.; PATERNÓ, F. (eds) Formal Methods in Human-Computer Interaction. London, Springer, 1997. Cap. 4, p. 75-92.

(Fortes \& Nicoletti, 1999) FORTES, R.P.M.; NICOLETTI, M.C. Automatic Diagnosis of Hyperdocuments Using a Family of Quantifiablè Metrics. In: SoST'99 (Symposium on Software Technology) Proceedings Buenos Aires - Argentina, September 1999, p. 62-71.

(Galvis, 1988) GALVIS, A. H. Ambientes de enseñanza aprendizage enriquecidos com computador. Boletin de Informatica Educativa. 1 (2), 117-139. Bogotá, dezembro de 1988.

(Garzotto et al., 1995) GARZOTTO, Franca; MAINETTI, Luca; PAOLINI, Paolo. Hypermedia Design, Analysis, and Evaluation Issues. Communications of the $A C M$, v.38, n.8, p.74-86, agosto 1995.

(Garzotto et al., 1996) GARZOTTO, Franca; MAINETTI, Luca; PAOLINI, Paolo. Information Reuse in Hypermedia Applications. In: HyperText, Washington DC - USA, p. 93104, 1996. Proceedings.

(Garzotto \& Paolini, 1999) GARZOTTO, Franca \& PAOLINI, Paolo. Design and Evaluation of Cultural Multimedia. http://www.archimuse.com/ichim99/abstraćts/prg_1047.html. (Ghezzi et al., 1991) GHEZZI, Carlo; MEHDI, J.; MANDRIOLI, Dino. Fundamentals od Software Engineering. Prentice-Hall International Editions. 1991. 
(Halasz, 1988) HALASZ, F. G. Reflections on Notecards: Seven Issues for the Next Generation of Hypermedia System. Communications of the ACM, v.31, n.7, p.836-852, julho 1988.

(Hatzmanikatis et al., 1995) HATZMANIKATIS, A.E.; TSALIDIS, C. T.; CHRISTODOULAKIS, D. Measuring the Readability and Maintainability of Hyperdocuments. Joumal of Software Maintanance: Research and Practice, v.7. p.77-90, março/abril 1995.

(ISO/DC8402, 1990) Quality Concepts and Terminology - Party One: Generic Terms and Definition, International Standards Organization.

(Kan, 1994) KAN, S. H. Metrics and Models in Software Quality Engineering. USA, AddisonWesley, 1994.

(Koster, 1995) KOSTER, Martijn. Robots in the Web: threat or treat? ConneXions, v.9, n.4, April 1995.

(Large, 1996) LARGE, A. Hypertext Instructional Programs and learner control: a research review. Education for Information, v.14, n.2, p.95-106, 1996.

(Lévy, 1995) LÉVY, P. As tecnologias da inteligência - o futuro do pensamento na era da informática. Editora 34. Rio de Janeiro, 1995.

(Machado, 1993) MACHADO, A. Máquina e imaginário. Editora da USP. São Paulo, 1993.

(Manns \& Coleman, 1988) MANNS, Tom \& COLEMAN, Michael. Software Quality Assurence. McMillian Education. 1988.

(Martins et al., 1999) MARTINS, Janae G.; RODRIGUEZ, Alejandro M.; MOÇO, Sueli, S.; BARCIA, Ricardo M. A Transformação do Ensino através do Uso da Tecnologia na Educação. In: Workshop de Informática na Escola, 5., Rio de Janeiro - RJ Brasil, 1999. Anais. p.571-579.

(Masetto \& Abreu, 1990) MASETTO, M. T. \& ABREU, M. C. O Professor Universitário em Aula. São Paulo, Mg. Ed. Associados, 1990.

(McCall et al., 1977) MCCALL, J.; RICHARDS, P.; WALTERS, G. Factors in Software Quality. três volumes, NTIS AD-A049-014. 015, 055, Novembro 1977.

(Moreira, 1987) MOREIRA, Mércia. A questão da produção e da avaliação do software educacional. In: Seminário o Computador e a Realidade Educacional Brasileira, 2. Belo Horizonte. UFMG/Centro Piloto de Informática na Educação, maio 1987.

(Nanard \& Nanard, 1995) NANARD, Jocelyne; NANARD, Marc. Hypertext Design Environments and the Hipertext Design Process. Communications of the Association of Computer Machinery, v.38, n.8, p.49-56, 1995.

(Nanard et al., 1998) NANARD, Jocelyne; NANARD, Marc; KAHN, Paul. Pushing Reuse in Hypermedia Design: Golden Rules, Design Patterns and Constructive Templates. In: HyperText, Pittsburgh PA - USA, 1998. Proceedings. p.11-20. 
(Neto et al., 1995) NETO, J. B., SOUZA, F. F., CYSNEIROS, P. G., FALCÃO, J. T. R., Hipertexto e Educação: uma Experiência com o Sistema Acqua. In: Simpósio Brasileiro de Informática na Educação, 6., Florianópolis - SC - Brasil, 1995. Anais.

(Netz, 1999) NETZ, Clayton, O Mundo Novo. Exame - Parte Integrante da Edição 700 da Exame. p.5, 1999.

(Pinkerton, 1994) PINKERTON, B. Finding what people want: experiences with the WebCrawler. In: International WWW Conference, $2^{\text {nd }}$. Chicago, USA, October 1994. Proceedings. p.17-20.

(Pressman, 1995) PRESSMAN, R. S. Engenharia de Software. Makron Books, São Paulo, 1995.

(Pressman, 1997) PRESSMAN, R. S. Software Engineering - A Practitioner's Approach. $4^{\text {th }}$ Edition, McGraw-Hill, USA, 1997.

(Rada, 1997) RADA, R. Hypermedia Solutions Limited and Virtual Education Maifesto. http://www.gnacademy.org/gnacademy/h/s/. (1997)

(Ramos \& Mendonça, 1991) RAMOS, E. \& MENDONÇA, I. V. O Fundamental na Avaliação da Qualidade do Software Educacional. In: Simpósio Brasileiro de Informática Educacional, 2., Porto Alegre - RS - Brasil, 1991. Anais.

(Reggini, 1990) REGGINI, H. C. El Pasajero de la gondola: reflexiones en torno a la education y a LOGO. Boletin de Informatica Educativa. 3 (1), 9-17. Bogotá, abril de 1990.

(Rocha, 1987) ROCHA, A.R.C. Análise e Projeto Estruturado de Sistemas. Editora Campus, Rio de Janeiro, 1987.

(Rocha, 1998) ROCHA, A. R. C. Planejamento e Avaliação da Qualidade de Software. In: Conferência Internacional de Tecnologia de Software (CITS), 9. Curitiba - PR, junho de 1998. Anais.

(Santibañez \& Fernandes, 1998) SANTIBAÑEZ, Miguel R. F.; FERNANDES, C. T. SICH: Uma Ferramenta para a Construção de Cursos Hipermídia na WWW. In: Simbósio Brasileiro de Informática na Educação, 9., Fortaleza - CE - Brasil, 1998. Anais [CD].

(Seraphim, 2000) SERAPHIM, E. Suporte Automático à Avaliação da Consistência Estrutural em WWW. 2000. Dissertação (Mestrado) - ICMC, USP. Em andamento.

(Silva et al., 1998) SILVA, Denise Pilar; DURM, Rafaël Van; DUVAL, Erik; OLIVIÉ, Henk. Adaptive Navigational Facilities in Educational Hypermedia. In: HiperText'98, Pittsburgh, USA, 1998. Proceedings. p.291-292.

(Silva et al., 1999) SILVA, A. S.; VELOSO, E. A.; GOLGHER P. .B.; RIBEIRO-NETO B.; ZIVIANI, N.; LAENDER, A.H.F. CobWeb - Um Coletor Automático de 
Documentos Web. In: Congresso Nacional da Sociedade Brasileira de Computação, XIX, XXVI SEMISH, Vol. 1, julho de 1999. Anais. p.233-247

(Sommerville, 1989) SOMMERVILLE, I. Software Engineering. Third Edition, Addison-Wesley, 1989.

(Squires \& Preece, 1996) SQUIRES, David \& PREECE, Jenny. Usability and learning: evaluating the potential of educational software. Computers Edu, v.27, n.1, p.1522. 1996.

(Stahl, 1990) STAHL, M. Software Educacional: características dos tipos básicos. In: Simpósio Brasileiro de Informática na Educação, 1., 34-46. Rio de Janeiro - RJ, novembro de 1990. Anais.

(Stotts et al., 1992) STOTTS, P. David; FURUTA, Richard; RUIZ, J. Cyrano. Hyperdocuments as Automata: Trace-Based Browsing Property Verification. In: European Conference on Hypertext, New York, 1992. Proceedings. p.272-281.

(Thackaberry \& Rada, 1998) THACKABERRY, C. W. \& RADA, R. Estimation Metrics for Courseware Maintenance Effort. http://www.iicm.edu/jucs_4_3/estimation_metrics_for_courseware/paper.html/.

(Thüring et al., 1995) THÜRING, Manfred; HANNEMANN, Jörg; HAAKE, Jörg M. Hypermedia and Cognition: Designing for Comprehension. Communications of the ACM, v.38, n.8, p.57-66, 1995.

(Yamada et al., 1995) YAMADA, Shoji; HONG, Junk-Kook; SUGITA, Shireharu. Development and Evaluation of Hypermedia for Museum Education: Validation of Metrics. ACM Transactions on Computer-Human Interaction, vol.2, n.4, p.284-307, dezembro 1995. 